MIICHIGAN RETIREMENT AND
DISABILITY RESEARCH CENTER
UNIVERSITY OF MICHIGAN

Promoting research on retirement, disability, and Social Security policy

\title{
Latent Work Capacity and Retirement Expectations
}

Italo Lopez Garcia, Nicole Maestas, and Kathleen J. Mullen 


\section{Latent Work Capacity and Retirement Expectations}

\author{
Italo Lopez Garcia \\ RAND
}

\author{
Nicole Maestas \\ Harvard Medical School \\ and NBER
}

\author{
Kathleen J. Mullen \\ RAND
}

September 2019

Michigan Retirement and Disability Research Center, University of Michigan, P.O. Box 1248. Ann Arbor, Ml 48104, mrdrc.isr.umich.edu, (734) 615-0422

\section{Acknowledgements}

The research reported herein was performed pursuant to a grant from the U.S. Social Security Administration (SSA) funded as part of the Retirement Research Consortium through the University of Michigan Retirement Research Center Award RDR18000002. The opinions and conclusions expressed are solely those of the author(s) and do not represent the opinions or policy of SSA or any agency of the federal government. Neither the United States government nor any agency thereof, nor any of their employees, makes any warranty, express or implied, or assumes any legal liability or responsibility for the accuracy, completeness, or usefulness of the contents of this report. Reference herein to any specific commercial product, process or service by trade name, trademark, manufacturer, or otherwise does not necessarily constitute or imply endorsement, recommendation or favoring by the United States government or any agency thereof.

\section{Regents of the University of Michigan}

Jordan B. Acker; Huntington Woods; Michael J. Behm, Grand Blanc; Mark J. Bernstein, Ann Arbor; Paul W. Brown, Ann Arbor; Shauna Ryder Diggs, Grosse Pointe; Denise llitch, Bingham Farms; Ron Weiser, Ann Arbor; Katherine E. White, Ann Arbor; Mark S. Schlissel, ex officio 


\title{
Latent Work Capacity and Retirement Expectations
}

\begin{abstract}
Understanding how health decline influences retirement decisions is fundamental for the design of targeted policies that encourage working longer. While there is wide agreement on the relevance of age-related health decline for determining labor supply and retirement decisions, the process of how health deterioration affects labor supply remains a black box. This paper explores the match between individuals' functional abilities and job demands in the national economy using a new methodology to measure work capacity. Specifically, we construct a onedimensional measure of individuals' work capacities by comparing an individual's own ability levels to the levels needed to perform different occupations, using new data containing individuals' ratings of the same 52 abilities included in the Occupational Information Network $\left(\mathrm{O}^{*} \mathrm{NET}\right)$ database. We find that a one-unit increase in the fraction of jobs for a given education level that an individual can do - our measure of work capacity - is associated with a 15 to 21 percentage point increase in labor force participation, a 10 to 17 percentage point decrease in the percentage of respondents receiving SSDI benefits, a 7 to 10 percentage point increase in the subjective percent chance individuals will work longer, a 9 to 12 percentage point increase in the chance that retired individuals will return to the labor force, and a 17 to 25 percentage point increase in the chance that individuals with disabilities will return to the labor force. The magnitudes of these associations are all economically relevant and exist even when controlling for health status.
\end{abstract}

\section{Citation}

Lopez Garcia, Italo, Nicole Maestas, and Kathleen J. Mullen. 2019. "Latent Work Capacity and Retirement Expectations." Ann Arbor, MI. University of Michigan Retirement and Disability Research Center (MRDRC) Working Paper; MRDRC WP 2019-400.

https://mrdrc.isr.umich.edu/publications/papers/pdf/wp400.pdf

\section{Authors' acknowledgements}

This research also was supported by grant number R01AG056239 from the National Institute on Aging. Its contents are solely the responsibility of the authors and do not represent the opinions or policy of SSA or any agency of the federal government. We thank Kate Bent and participants of the 2019 MRDRC Workshop and 2019 Retirement and Disability Research Consortium Conference for helpful comments and suggestions, and Michael Jetsupphasuk and David Zingher for excellent research assistance. 


\section{Introduction}

The U.S. population is aging rapidly, in part due to dramatic gains in life expectancy. The share of individuals ages $65+$ is projected to reach 16.9 percent in 2020 and 20.6 percent by 2030 (U.S. Census Bureau 2018). As a consequence, labor force growth and, therefore, economic growth have slowed (Maestas, Mullen, and Powell 2016) and the long-run fiscal health of Social Security and Medicare has eroded (Gruber and Wise 2004). One policy response is to encourage older individuals to delay retirement and work longer, say, by raising eligibility ages for claiming Social Security and Medicare benefits. If older workers worked longer, their additional payroll tax contributions would help shore up the social insurance system and they would draw benefits from the system for fewer years, offsetting some of the social costs of living longer. At the individual level, work is an important social determinant of health (Wilkinson and Marmot 2003).

But even if working longer were a net positive for the U.S. economy, it is not obvious that all older individuals could work longer or would even want to work longer. This concern has spurred interest in understanding the factors that affect the timing of retirement among older workers. One important driver of early retirement is age-related declines in health (see e.g., McGarry 2004). Health problems arise more frequently with age, and their effects on employment may be greater among individuals who hold jobs that are physically or cognitively demanding. Health problems may also limit job mobility by reducing the number of alternative occupations an individual with a given level of education could do, should they separate from or be separated from their current job.

The question of who can and cannot work longer is wide open. On average, there appears to be significant excess work capacity among today's older Americans 
relative to earlier cohorts (Coile, Milligan, and Wise 2017; Cutler, Meara, Powell, and Richards-Shubik 2014). Biodemographic research corroborates this; individuals of a given chronological age today are biologically younger than same-aged individuals of the past by about a decade (Vaupel 2010). But while these estimates provide an idea of how much additional employment older workers could potentially achieve, assuming no change in job demands, they cannot tell us about the distribution of work capacity in the economy, how it evolves with age or varies with onset of health problems, and how abilities and job demands interplay and evolve over time.

We make progress on this question through several contributions. First, we develop a new way of measuring work capacity. Our method starts from the insight that if individuals' functional abilities were measured in the same terms as the functional requirements of occupations, then one could compare an individual's ability levels to different occupations' ability requirements and deduce which occupations the individual could likely perform. To create such a data set, we asked a nationally representative sample of Americans to rate their abilities along 52 dimensions, corresponding exactly to the 52 dimensions of ability used by the Occupational Information Network (O*NET) to rate the occupational ability requirements for nearly 800 occupations in the U.S. economy. The survey items, scales, and scale anchors were exactly the same as those used by $\mathrm{O}^{*} \mathrm{NET}$ to rate occupations. Combining our new survey data with the O*NET database, we then determine for each respondent their occupation-specific work capacity—that is, whether they likely can or cannot perform a given occupation—by comparing their reported levels of functional ability to those required by each occupation. Once we determine an individual's set of potential occupations-conditional 
on their education-we define total work capacity as the share of all occupations for a given educational level in the national economy that the individual can do.

We next investigate the properties of our new work capacity measure, comparing two alternative versions. The relatively conservative version requires an individual to meet or exceed all of an occupation's important ability requirements in order to be credited with the occupation. The more generous version gives credit for an occupation as long as the individual meets most, but not necessarily all, occupational requirements. We show how the two measures of work capacity vary across our nationally representative sample, how they compare to one another, how they vary by age, and how they compare to average occupational requirements in the national economy.

Finally, we test whether our new work capacity measure is useful for understanding current and future labor force participation decisions by testing whether work capacity adds explanatory power to employment models, disability benefit receipt, future retirement intentions, and future return-to-work intentions among those not in the labor force.

We have three main findings. First, average abilities, overall and across four domains (cognitive, psychomotor, physical, and sensory ability), are high relative to average occupational demands. Second, we find that age-related declines in ability are modest, with physical abilities declining the most by age 71 and cognitive abilities declining the least. As a result, these observed declines are largely inframarginal to job demands, at least on average. This suggests that potential occupation sets are relatively stable with age. Third, our work capacity measures have predictive power for all of the different objective and subjective labor supply outcomes we examined. We show that they reflect underlying health to an important degree, but also contribute 
explanatory variation independent of health. We find that an increase in an individual's work capacity from being unable to do any job to being able to do all jobs given the individual's education level is significantly associated with a 15 to 21 percentage point increase in labor force participation and a 10 to 17 percentage point decrease in the percentage of recipients of Social Security Disability benefits. The same change in an individual's work capacity is associated with a 7 to 10 percentage point increase in the subjective expectation of working past age 65 (if the individual is younger than 65) or past age 70 (if the individual is between ages 65 and 71), a 9 to 12 percentage point increase in the subjective expectation that retired individuals will return to the labor force, and a 17 to 25 percentage point increase in the subjective expectation that individuals with disabilities will return to the labor force. The magnitudes of these changes are all economically relevant and reflect that our measures of work capacity contribute explanatory variation independent of standard health measures alone, coming specifically from the (mis)match between abilities and job demands.

Our findings advance the literature in several ways. Previous papers have studied how age-related mismatches between abilities and job demands influence labor supply and retirement outcomes. Using data on cognitive and physical abilities from the Health and Retirement Study (HRS) and job demands from O*NET, Hudomiet et al. (2017) study the effect of mismatches between actual abilities and job demands on retirement expectations focusing, by necessity, on a limited number of dimensions, rather than a comprehensive assessment of mismatches between multiple job demands and actual level of abilities. Using the same data sources, Belbase et al. (2015) construct a susceptibility index, which captures how likely the abilities required for an occupation are to decline with age for all occupations in the economy. By relating the 
index to retirement behaviors, they find that workers in occupations that rely more on abilities with faster age-decline tend to retire earlier. A limitation of their approach is that they must identify abilities prone to age-decline through external literature review rather than by observation of HRS respondents. Different from these papers, our new survey data harmonized with the O*NET database enables us to comprehensively compare individuals' functional status across all $52 \mathrm{O}^{*} \mathrm{NET}$ abilities to the levels of those same abilities required for nearly all occupations in the national economy.

\section{Data}

\subsection{O*NET Database and the American Work Capacity and Abilities Survey}

We use data from two sources. The first is the U.S. Department of Labor's $\mathrm{O}^{*} \mathrm{NET}$ database, which contains comprehensive information about the job requirements of all occupations in the U.S. economy. In this paper, we focus on occupational ability requirements. O*NET defines abilities as "relatively enduring attributes of an individual's capability for performing a particular range of different tasks" (Fleishman, Costanza, and Marshall-Mies 1999). Abilities are distinct from skills, which are "proficiencies that are developed through training or experience" (Tsacoumis and Willison 2010). O*NET identifies 52 abilities broadly applicable to jobs in the "world economy," and grouped into four functional domains: cognitive, psychomotor, physical, and sensory abilities. Abilities in the cognitive domain include, for example, oral and written comprehension and expression, fluency of ideas and originality, problem sensitivity, deductive and inductive reasoning, information ordering and mathematical reasoning, pattern recognition and perceptual speed, spatial orientation and visualization, and selective attention and time sharing. Psychomotor abilities include arm-hand steadiness, manual and finger dexterity, multilimb coordination and speed of 
limb movement, rate control and reaction time. Physical abilities include measures of strength, stamina, flexibility, and gross body coordination. Sensory abilities include aspects of vision, hearing sensitivity and sound localization, speech recognition, and speech clarity. Appendix Table 1 lists the 52 abilities and their definitions.

Each occupation is rated along these 52 dimensions of ability by eight independent occupational analysts who follow standardized procedures (Fleisher and Tsacoumis 2012). For each ability, analysts rate the importance of the ability for the performance of the occupation's associated work activities and tasks, and the level of ability needed to carry out those work activities and tasks. Importance is rated on a scale of 1 to 5 , where $1=$ "Not Important," 2="Somewhat Important," $3=$ "Important," 4="Very Important," and 5="Extremely Important." The level of ability needed is rated on a scale from 0 to 7 , where 0 means not relevant and 7 is the highest level of ability. ${ }^{1}$ Each ability level scale has a unique set of scale anchors that provide an example of an activity that could be done at that ability level. For example, the ability arm-hand steadiness has anchors at levels 2,4 , and 6 corresponding to the degree of arm-hand steadiness needed to "light a candle," "thread a needle," and "cut facets in a diamond," respectively. ${ }^{2}$ Final ability level needed and importance ratings for each occupation are averages of the individual ratings provided by the eight raters. ${ }^{3}$

${ }^{1}$ Abilities that are not important for an occupation are assigned a required ability level of 0 .

${ }^{2}$ A description of the ability scales and their level anchors can be found at https://www.onetcenter.org/dl_files/MS_Word/Abilities.pdf, which was used to elicit ability ratings from job incumbents at the beginning of the O*NET program. O*NET now obtains ability ratings from occupational analysts, but the rating scales and level anchors are the same.

${ }^{3} \mathrm{O}$ NET ability rating is ongoing and performed in cycles; approximately 10 percent of occupations are rerated each year, and new occupations are added as needed. 
O*NET uses the Standard Occupational Classification (SOC) 2010 system to identify occupations at a detailed, six-digit level. Six-digit occupations are narrowly defined to include workers who perform similar job tasks. O*NET further subdivides certain six-digit occupations (approximately 6\%) to an eight-digit level using its O*NETSOC taxonomy, which is identical to the SOC taxonomy for six-digit occupations that are not further subdivided. For example, the six-digit SOC code "33-3051 Police and Sheriff's Patrol Officers," is further subdivided by O*NET into "33-3051.01 Police Patrol Officers," who "Patrol assigned area to enforce laws and ordinances, regulate traffic, control crowds, prevent crime, and arrest violators" and "33-3051.03 Sheriffs and Deputy Sheriffs" who "Enforce law and order in rural or unincorporated districts or serve legal processes of courts." In contrast, the six-digit SOC code "29-2051 Pharmacy Technicians" who "Prepare medications under the direction of a pharmacist" has no further subdivisions. The O*NET-SOC taxonomy also includes some "new and emerging occupations" that have not yet been added to the SOC. We use the O*NET 22.1 Database (October 2017 Release), which contains 773 six-digit SOC occupations and 966 O*NET-SOC occupations (which encompass the 773 SOC occupations). ${ }^{4}$ In this paper, we work at the six-digit level, averaging required ability levels across eightdigit occupations to obtain the average required level for the six-digit occupation.

Our second data set comes from the American Work Capacity and Abilities Survey, a survey we administered in 2018 to participants in the RAND American Life Panel (ALP), a nationally representative sample of Americans ages 18 and older who

\footnotetext{
${ }^{4}$ These figures give the number of occupations for which data is collected. The database includes an additional 136 six-digit SOC occupations for which data is not collected. These include military occupations and occupations in the catch-all category "All Other" that are not classified elsewhere.
} 
speak English or Spanish and who have agreed to participate in regular, online social science surveys. ${ }^{5}$ Specifically, for each of the 52 O*NET abilities, we asked respondents to rate their own level of ability, using the same scales and level anchors that the O*NET analysts use to rate occupational requirements. The innovation of this technique is that it measures individuals' functional abilities, which are asked about in general and not in relation to their current job or past jobs, in the same terms and on the same scales as occupational requirements are measured.

The instructions provided to survey respondents stated: "In this survey, you will be asked to rate your level of functioning for a series of different abilities. When giving your rating, please rate your current level of ability, not what you were able to do in the past or what you could do in the future with additional training. If you use an assistive device (e.g., glasses), please rate your ability when using the assistive device." For each question, we first defined an ability (using the same language as $\mathrm{O}^{*} \mathrm{NET}$ ) and we then asked the respondent to rate their level of ability on a scale from 1 to 7 , with three anchor points (using the same anchors as $\mathrm{O}^{*} \mathrm{NET}$ ). Respondents who could not perform any level of ability were instructed to select a response button marked "I cannot do any level of this ability" (which we subsequently recoded as 0 in our analysis data set). Respondents were told that these examples are "meant to help you find your own rating with the scale; do not focus on whether you perform the specific activity, which may come from an unfamiliar context." Appendix Figure 1 is a screenshot of the survey question about arm-hand steadiness, as viewed by a respondent who rated their armhand steadiness at level 2 .

\footnotetext{
${ }^{5}$ For more information about the ALP, see https://www.rand.org/research/data/alp.html. The "American Work Capacity and Abilities Survey" was survey module number 508.
} 
Only after they rated their abilities, respondents were asked about their current labor force status (e.g., "working now," "unemployed an looking for work," "retired," etc.) and, if currently working, their job title, descriptions of three to five "usual activities or duties at this job," and two digit industry, all of which we used to code their current occupation at the six-digit SOC level. ${ }^{6}$ See Lopez Garcia, Maestas, and Mullen (2019) for more details on the occupation coding. Next, respondents were asked a question about their subjective expectation on a scale of 0 to 100 of the chances "that you will be working full-time after you reach age 65" (if working, unemployed, or temporarily laid off, and if age<65), "that you will be working full-time after you reach age 70" (if working, unemployed, or temporarily laid off, and if age $>=65$ and age $<70$ ), or "that you will return to work sometime in the future" (if out of the labor force because the respondent is retired, disabled, or "homemaker," regardless of age). Finally, respondents were asked to rate their health on a scale from excellent (1) to poor (5), indicate whether they have "any impairment or health problem that limits the kind or amount of paid work you can do" (yes/no), and indicate whether they receive Social Security Disability Insurance (SSDI) benefits (yes/no).

\subsection{Summary statistics}

Table 1 presents descriptive statistics for our analysis sample. We invited all English-speaking ALP participants ages 18 to 70 to take the survey between July 18, 2018 , and September 17,2018 . The survey had a response rate of $82 \%(N=2,270) .^{7}$ Because the focus of this paper is on retirement intentions, we restrict our analysis

\footnotetext{
${ }^{6}$ Respondents who were not currently working were asked for the job title, three to five usual activities, and industry of their "last paid job." Those who never worked could check the response option "I never had a paying job."

${ }^{7}$ One of the respondents turned 71 before the survey closed in September 17, 2018.
} 
sample to those ages 35 to 71 . We further exclude respondents with any missing ability rating or missing health variables. We use survey weights to match the demographic distribution of the sample to that of the Current Population Survey. Of the respondents in our sample, 51 percent are female, 69 percent are married, 69 percent are white, non-Hispanic, 12 percent are black, non-Hispanic, 16 percent are Hispanic and 4 percent are another race/ethnicity. In terms of age, 41 percent are younger than 50, 29 percent are between ages 50 and 59, and 30 percent are between ages 60 and 71 . Regarding education, 39 percent have a high school degree or less, 28 percent some college education, 17 percent a bachelor's degree, and 16 percent a postgraduate degree. Regarding labor force status, 68 percent are active workers, 3 percent unemployed or temporarily laid-off, 7 percent disabled, 17 percent retired, and 5 percent homemakers. Individuals in the sample are relatively healthy, with 43 percent reporting excellent or very good health, 39 percent in good health, and only 18 percent in fair or poor health. Approximately one-fifth report a work-limiting health problem, and 10 percent report receiving SSDI benefits. 
Table 1. Summary statistics, ALP sample

\begin{tabular}{|c|c|}
\hline & $\%$ (Weighted) \\
\hline Percent female & $51.2 \%$ \\
\hline Percent married & $68.5 \%$ \\
\hline Percent white non-Hispanic & $68.5 \%$ \\
\hline Percent black non-Hispanic & $11.7 \%$ \\
\hline Percent Hispanic & $15.9 \%$ \\
\hline Other race & $3.9 \%$ \\
\hline \multicolumn{2}{|l|}{ Age group } \\
\hline 35-39 & $12.8 \%$ \\
\hline $40-44$ & $16.5 \%$ \\
\hline $45-49$ & $11.8 \%$ \\
\hline $50-54$ & $15.9 \%$ \\
\hline $55-59$ & $12.7 \%$ \\
\hline $60-64$ & $14.8 \%$ \\
\hline $65-71$ & $15.4 \%$ \\
\hline \multicolumn{2}{|l|}{ Education } \\
\hline High school or less & $39.3 \%$ \\
\hline Some college & $27.5 \%$ \\
\hline Bachelor's degree & $17.1 \%$ \\
\hline Postgraduate & $16.1 \%$ \\
\hline \multicolumn{2}{|l|}{ Labor status } \\
\hline Working now & $68.0 \%$ \\
\hline Unemployed and looking & $2.8 \%$ \\
\hline Temporarily laid off & $0.5 \%$ \\
\hline Disabled & $7.0 \%$ \\
\hline Retired & $16.5 \%$ \\
\hline Homemaker & $4.9 \%$ \\
\hline \multicolumn{2}{|l|}{ Health Status } \\
\hline Excellent & $8.1 \%$ \\
\hline Very good & $34.6 \%$ \\
\hline Good & $39.2 \%$ \\
\hline Fair & $14.1 \%$ \\
\hline Poor & $4.0 \%$ \\
\hline Work-limiting health problem & $21.0 \%$ \\
\hline Receive SSDI & $9.5 \%$ \\
\hline Number of observations & 1,934 \\
\hline
\end{tabular}

Note: Sample excludes individuals with any missing abilities or health information 
Table 2 presents summary statistics for our main outcomes: respondents' subjective probability of working full-time past age 65 or 70 (depending on current age), and their subjective probability of returning to work in the future if currently retired or disabled. Among those currently in the labor force (working or unemployed) who are younger than 65 , the average self-reported chance of working full-time past age 65 is 61 percent. Only 5 percent report a zero chance of working full-time after age 65 , and fewer than one-third-29 percent-report less than a 50 percent chance of working fulltime after age 65 . A substantial fraction of respondents (14 percent) report exactly 50 percent; excess mass at 50 percent is a common feature of subjective probability data and may indicate epistemic uncertainty among some respondents (Hurd, 2009). Approximately 58 percent of labor force participants younger than 65 report a greaterthan-50 percent chance of working full-time after age 65 . Among labor force participants ages 65 to 71, the average self-reported percent chance of working full-time after age 70 is 55 percent. $^{8}$ Just under four in 10 older labor force participants report their chance of working full-time after age 70 as less than 50 percent, and more than half (53 percent) report chances greater than 50 percent.

The last two rows of Table 2 provide summary statistics on the percent chance of returning to work among those not in the labor force who are either retired or disabled. ${ }^{9}$ The average percent chance of returning to work is 20 percent among retired respondents and 21 percent among disabled respondents. Disabled respondents are more likely than retired respondents to report no chance of returning to work (43 versus

\footnotetext{
${ }^{8}$ As noted above, one respondent turned 71 after being invited and before completing the survey.

${ }^{9}$ We omit "homemakers" from the analysis, under the assumption that this group has potentially little attachment to the labor force.
} 
32 percent), but among both groups a large majority report their return-to-work chances as less than 50 percent ( 82 and 80 percent of disabled and retired respondents, respectively). Nonetheless, it is notable that nearly 20 percent of disabled respondents (most of whom receive SSDI benefits) report their chances of returning to work as 50 percent or greater. This is in line with recent evidence showing that return-to-work rates among SSDI recipients are significantly lower than other groups, but they have been rising in recent years (Maestas forthcoming).

Table 2. Subjective expectations about work in the future

\begin{tabular}{|c|c|c|c|c|c|c|c|c|}
\hline \multirow[b]{2}{*}{ Subjective Probability of: } & \multirow[b]{2}{*}{$\mathbf{N}$} & \multirow[b]{2}{*}{ Mean } & \multirow[b]{2}{*}{ Sd. } & \multicolumn{5}{|c|}{ Percent with Response } \\
\hline & & & & 0 & $1-49$ & 50 & $51-99$ & 100 \\
\hline Working past age 65 & 1,175 & 61.1 & 31.8 & $4.9 \%$ & $23.6 \%$ & $13.7 \%$ & $44.6 \%$ & $13.3 \%$ \\
\hline Working past age $\mathbf{7 0}$ & 121 & 55.4 & 36.1 & $10.9 \%$ & $28.0 \%$ & $8.2 \%$ & $37.0 \%$ & $15.8 \%$ \\
\hline $\begin{array}{l}\text { Returning to work in the } \\
\text { future if retired }\end{array}$ & 390 & 19.9 & 29.6 & $31.9 \%$ & $48.0 \%$ & $9.2 \%$ & $8.8 \%$ & $2.1 \%$ \\
\hline $\begin{array}{l}\text { Returning to work in the } \\
\text { future if disabled }\end{array}$ & 157 & 21.1 & 26.4 & $42.5 \%$ & $39.9 \%$ & $4.2 \%$ & $7.7 \%$ & $5.7 \%$ \\
\hline
\end{tabular}

Next, we show the age-ability profiles for our sample. Figure 1 plots respondents' average reported ability level by O*NET ability domain and five-year age group. To create each age profile, we first compute the respondent-level average across all abilities in a given domain (equally weighted). Then we plot the average across all respondents in a given age group, weighted by the ALP sampling weights. The four O*NET domains are cognitive (consisting of 20 abilities), psychomotor (11 abilities), physical (nine abilities) and sensory (12 abilities). Recall that all abilities are measured on a 0 to 7 scale. The most notable feature of the figure is that the ability profiles are relatively stable by age. Average cognitive ability is 4.6 for individuals in their late $30 \mathrm{~s}$, 4.3 among respondents in their $50 \mathrm{~s}$, and 4.4 among respondents in their $60 \mathrm{~s}$. Average 
psychomotor ability is 4.9 among respondents in their late 30 s and just slightly lower4.6-among respondents in their late 60s. Average physical ability declines the most, from 4.5 among respondents in their late 30 s to 3.8 among those in their late $60 \mathrm{~s}$. Finally, average sensory ability declines over the 40 s, from 4.7 to 4.4 , but thereafter holds steady through age 71 . Although when shown at full scale the curves in Figure 1 appear similar, the confidence bands around each curve (not shown) are narrow and the patterns of differential decline are statistically distinct.

Figure 1. Average ability levels by domain and five-year age group

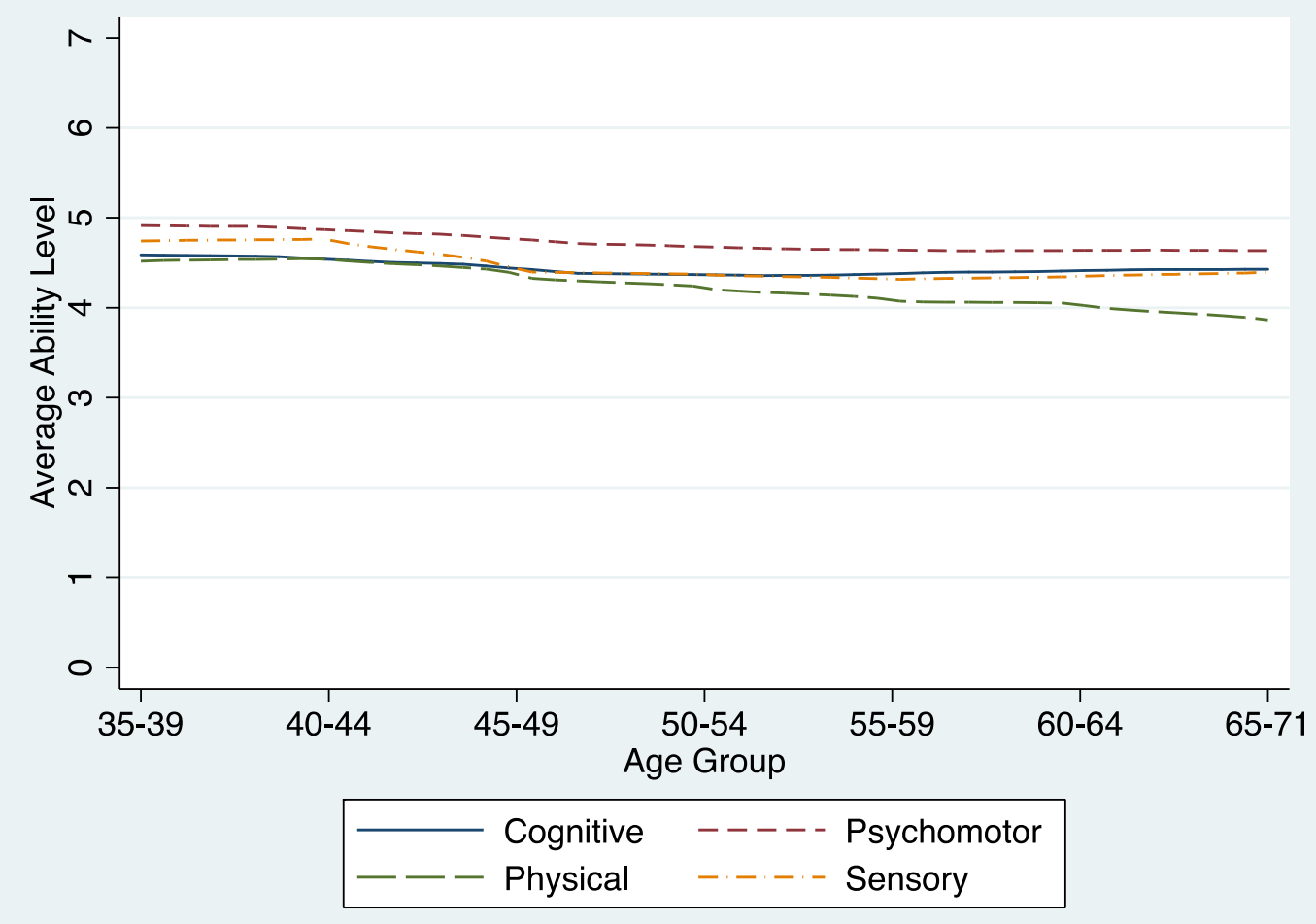

However, abilities alone do not determine work capacity; work capacity is determined by the match between an individual's abilities and occupational requirements. Before turning to the match between respondent abilities and occupational requirements, we briefly examine the latter-average occupational requirements in the U.S. Table 3 shows the average minimum ability requirement for 
each ability domain, first across all occupations in the O*NET database, and then across occupations requiring a certain educational level. To obtain the averages across all occupations in Table 3, we first compute the occupation-level average across all abilities in a given domain (with abilities equally weighted), and then for each ability domain, we find the weighted average across all occupations, where the weights are each occupation's share of jobs in the national economy (obtained from the Bureau of Labor Statistics' Occupational Employment Statistics program). ${ }^{10}$ To obtain averages across occupations requiring a certain educational level, we follow the same procedure as before but we use as weights the occupation's share of jobs requiring a given educational level. These are obtained by combining information on an occupation's share of jobs in the national economy with educational requirements for each occupation, extracted from the O*NET Education and Training requirements dataset. The most striking feature of the table is that the average minimum ability levels needed for occupations in the U.S. economy-across all occupations and across occupations requiring a given educational level—are quite low; in fact, much lower than the average ability levels in the population. For example, the average minimum physical ability required by occupations is 1.3 overall, and the average minimum physical ability necessary for occupations that require only a high school degree or less is 1.6; yet Figure 1 shows that the average 65 to 71 year old has an average physical ability of 3.8 , more than twice as high. Similarly, most cognitively demanding jobs-those held predominantly by individuals with postgraduate degrees_-require an average minimum

\footnotetext{
${ }^{10}$ The Occupational Employment Statistics (OES) gives the number of jobs for each occupation in the national economy. See https://www.bls.gov/oes/home.htm. To obtain job shares by education, we use the distribution of jobs by education for each occupation in the O*NET training requirements data.
} 
cognitive ability of 3.3 , well below the average cognitive ability level of 65 to 71 year old in our sample (4.4, see Figure 1). This suggests that, though underlying abilities may decline somewhat with age, these declines may be largely inframarginal relative to job requirements. This in turn suggests that individual work capacity itself (that is, the occupations one's abilities enable one to do) may be relatively stable with age. In the next section, we turn to how we measure individual work capacity.

Table 3. Average occupational demands in national economy, overall and by educational level

\begin{tabular}{lccccc}
\hline & & \multicolumn{4}{c}{ Occupations Requiring: } \\
\cline { 3 - 6 } Ability Domain & $\begin{array}{c}\text { Occupation } \\
\text { s }\end{array}$ & $\begin{array}{c}\text { High school } \\
\text { or less }\end{array}$ & $\begin{array}{c}\text { Some } \\
\text { college }\end{array}$ & $\begin{array}{c}\text { Bachelor's } \\
\text { degree }\end{array}$ & $\begin{array}{c}\text { Postgraduat } \\
\text { e }\end{array}$ \\
\hline \hline Cognitive & 2.78 & 2.53 & 2.88 & 3.15 & 3.30 \\
Psychomotor & 1.65 & 1.94 & 1.57 & 1.07 & 1.06 \\
Physical & 1.25 & 1.58 & 1.12 & 0.61 & 0.64 \\
Sensory & 1.85 & 1.87 & 1.82 & 1.80 & 1.80 \\
\hline \hline
\end{tabular}

Source: Authors' tabulations of O*NET 22.1 Database (October 2017 Release) and Occupational Employment Statistics data.

\section{Measuring work capacity}

We conceive of an individual's "work capacity" as the fraction of nationally available jobs an individual can do given their educational level. Importantly, the measure is based solely on the relationship between the individual's cognitive, physical, psychomotor, and sensory abilities and the corresponding levels required by each potential occupation in their education set. It purposefully does not take into account whether the individual also meets the specific skill requirements for an occupation, since our focus here is on health-related functional abilities. As discussed in Lopez Garcia, Maestas, and Mullen (2019), other possible conceptual definitions of work capacity are 
the fraction of occupations that an individual can perform (i.e., to assess how transferable are an individual's abilities to other occupations) or the individual's potential earnings in the occupations they can perform. Such measures can be constructed with and without conditioning on education (to assess how much education requirements constrain work capacity). Additionally, one can consider the fraction of jobs or occupations an individual can do in the national economy and also in their local labor market (to assess the degree of excess work capacity in local areas). The definition we use here corresponds most closely with the individual's employment prospects in the national economy.

\subsection{Occupation-specific and total work capacity}

We begin by constructing measures of an individual's ability to perform an occupation's required tasks. Our first step is to compare individual i's ability level $k, \theta_{i, k}$, to the level of $k$ required to perform occupation $j, c_{j, k}$. If $\theta_{i, k} \geq c_{j, k}$, then we classify the individual as having the required level of that ability for that occupation. If $\theta_{i, k}<c_{j, k}$, then the individual is classified as not having the required level of that ability for that occupation. For each potential occupation, we create $K=52$ indicators summarizing which ability requirements the individual meets.

The second step is to combine the information from the 52 indicators to estimate whether the individual has the ability profile to perform the occupation, or their occupation-specific work capacity $O W C_{i, j}$. There are numerous ways to implement this aggregation, and the alternatives vary in how conservative or generous is the measure in crediting an individual with a given occupation. We use two definitions of $O W C_{i, j}$ that can be interpreted as the fraction of an occupation an individual can do (and therefore take a value between 0 and 1). The first is a "product" measure (so named because it 
uses the product operator) that requires a person to have all abilities that are "important" for an occupation at or above the levels required for the occupation in order to be credited with the capacity to perform the occupation:

$$
O W C_{i, j}^{P}=\prod_{\substack{k=1 \\\left\{k: I M_{j, k} \geq 3.0\right\}}}^{K} 1\left(\theta_{i, k} \geq c_{j, k}\right),
$$

Where $I M_{j . k}$ is the importance ability rating $k$ for occupation $j$. An importance rating of 3.0 or greater corresponds to abilities that are "important," "very important," or "extremely important." This measure is relatively strict since if $\theta_{i, k}$ falls below even $c_{j, k}$ on even just one of the important abilities, then $O W C_{i, j}^{1}=0$ and the individual is not credited with the ability to perform the occupation.

An alternative approach is to give the individual partial credit for an occupation where they possess most (but not necessarily all) of the occupation's required abilities. Our second measure is a "weighted sum" measure that allows for partial credit in the event there are any missing abilities, even if they are important to the occupation:

$$
O W C_{i, j}^{S}= \begin{cases}1, & \sum_{k=1}^{K} \pi_{j, k} 1\left(\theta_{i, k} \geq c_{j, k}\right) \geq T \\ 0, & \text { otherwise }\end{cases}
$$

where each ability is weighted by its relative importance $\pi_{j, k}=\left(I M_{j . k}-1\right) / \sum_{k=1}^{K}\left(I M_{j, k}-\right.$ 1) (such that $\sum_{k=1}^{K} \pi_{j, k}=1$ ) and $T$ is some threshold above which an individual is considered able to do any given job. ${ }^{11}$ Lower values of $T$ make the measure more generous (crediting more people with partial abilities with the ability to perform the

\footnotetext{
${ }^{11}$ We subtract 1 from the importance rating so that abilities with a rating of 1 ("not important") are not counted in the construction of the weighted sum, since the required level is set to 0 for an ability with an importance rating of 1 .
} 
occupation), while higher values of $T$ make it more conservative (crediting fewer people with partial abilities with the occupation). In the extreme, $T=1$, this measure becomes equivalent to the product measure in equation (1) (assuming also that all important abilities are given weight 1 and unimportant abilities are given weight 0 ). We set $T=0.91$, that is, we require individuals to be able to do at least 91 percent of an occupation in order to receive credit for the occupation. ${ }^{12}$

Finally, for each measure of occupation-specific work capacity, $m=P, S$, we measure "total work capacity" as the fraction of jobs that require a given educational level that can be performed by individual $i$ :

$$
T W C_{i}^{m}=\sum_{j=1}^{J} \omega_{j \mid E d} * O W C_{i, j}^{m},
$$

where $\omega_{j \mid E d}$ is occupation j's share of all jobs held by workers with education $E d$, and where $E d$ is always chosen to be the educational level of person $i$. We use occupation's shares of jobs by educational level in order to obtain a work capacity measure that still increases with ability, but also reflects the fact that some occupations are not accessible to all individuals depending on the occupation's minimum education requirements.

To fix ideas with a simple example, suppose there is only one ability that matters to perform two occupations, one that requires low skills (Occupation 1) and another one that requires high skills (Occupation 2), so that everyone with low education works in Occupation 1 and no one with low education works in Occupation 2 (then $\omega_{1 \mid \text { low }}=1$ and $\omega_{2 \mid l o w}=0$ ), and most individuals with high education work in Occupation 2 (say

\footnotetext{
${ }^{12}$ We choose $T=0.91$ because 75 percent of employed individuals in our sample can perform at least 91 percent of the required abilities for their own occupation. See Lopez Garcia et al. (2019) for more details on how these and other job-specific work capacity measures are constructed and validated in our data.
} 
$90 \%$ ), with the remainder working in Occupation 1 (then $\omega_{1 \mid \text { high }}=0.1$ and $\omega_{2 \mid \text { high }}=$ 0.9). Consider an individual who is able to do Occupation 1 but not Occupation 2 . If he has low education, then his work capacity is $1(=1 * 1+0 * 0)$; on the other hand, if he has high education, then his work capacity is $0.1\left(=0.1^{*} 1+0.9^{*} 0\right)$. Thus, measured work capacity increases with ability but is determined by the relationship between the individual's ability and the economy's occupational demands, conditional on educational level. Two individuals with the same ability levels but different educational levels may have different levels of total work capacity in our framework, depending on the occupation set available to a worker with a given educational level.

In the next subsection, we describe the distributions of the two measures of work capacity and how they relate to one another, to age, and to self-reported health status.

\subsection{Empirical patterns}

Figure 2 displays the cumulative distribution function for each of the two measures of work capacity. From the figure, it is apparent that the more conservative product measure is skewed toward zero while the more generous weighted sum measure is skewed toward one. For example, 27 percent of the sample has work capacity of less than 0.05 (that is, they can do less than 5 percent of jobs for their educational level based on their abilities) based on the product measure, while just 10.4 percent of the sample can do less than 5 percent of jobs for their educational level based on the weighted sum measure. On the other hand, only 10.7 percent of individuals are classified as able to do more than 95 percent of jobs for their educational level based on the product measure, compared with 44.6 percent based on the weighted sum measure. The mean and median of the product measure are 0.39 and 0.27 , respectively. The mean and median of the weighted sum measure are 0.70 and 
0.88 , respectively. The standard deviations of the two measures are very similar: 0.37 for the product measure and 0.36 for the weighted sum measure.

Figure 2: Cumulative distributions of measures of work capacity

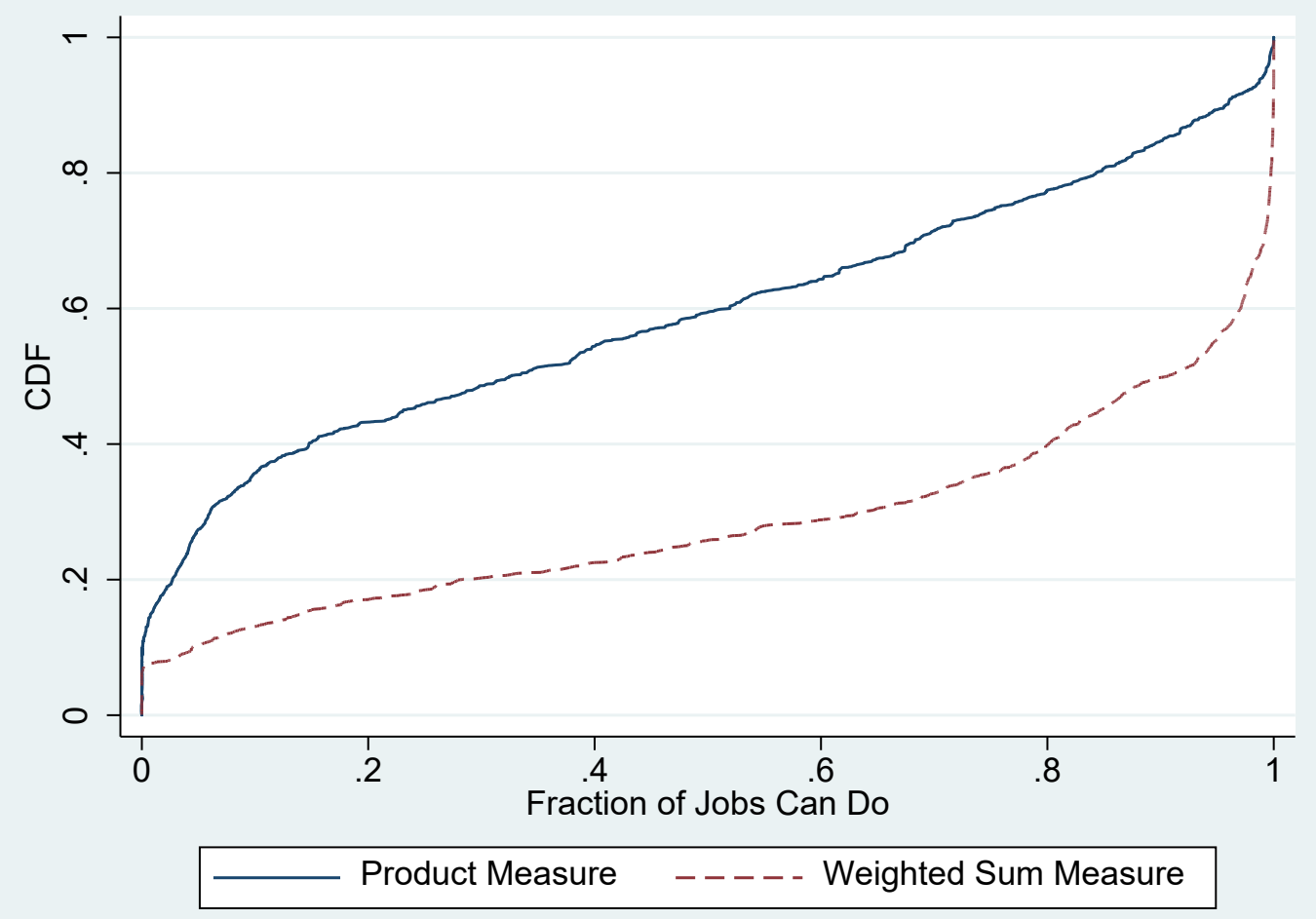

Figure 3 shows a scatterplot of the two work capacity measures, with a 45-

degree line for reference. With only a few exceptions, the product measure is lower than the weighted sum measure for a given individual. ${ }^{13}$ Interestingly, there is a wide range of work capacity as measured by the weighted sum measure, conditional on a product measure of zero. That is, individuals who are missing at least one "important" ability for every possible occupation may still retain enough of the other (important) abilities to be

\footnotetext{
${ }^{13}$ There are 92 individuals with a weighted sum measure of zero and a positive product measure. This is possible because there are a few occupations with a small number of abilities rated three to five on importance and a large number rated two on importance. The weighted sum for such occupations may be positive but below the threshold of 0.91 . Note the vast majority of these cases (84) have a product measure below 0.01 .
} 
able to perform a large fraction of occupations according to the weighted sum-based measure. It is also the case that individuals with weighted sum work capacity equal to 1 (classified as able to do 100 percent of jobs at their educational level) have a wide range of classifications on the product measure, which imposes a large penalty for missing just one ability important to performing a given occupation.

Figure 3: Scatterplot of product measure versus weighted sum measure

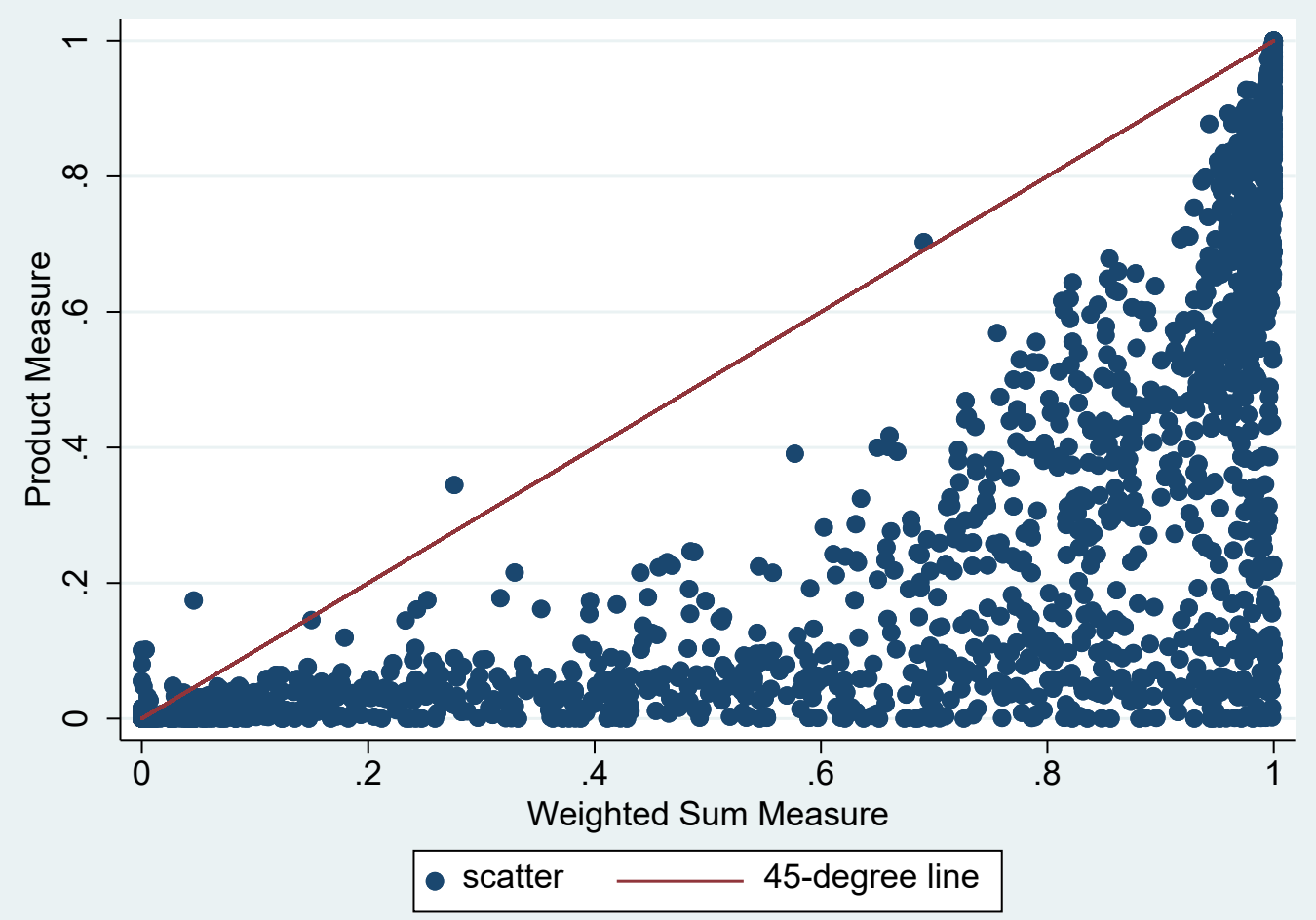

Since we are interested in how work capacity relates to retirement intentions, Figure 4 plots mean work capacity by five-year age group for each measure. Both measures show slight declines from age 35 to 45 , though the decline is only statistically significant for the product measure. Perhaps surprisingly, neither work capacity measure exhibits a decline at older ages. This is because, as we saw in Section 2, ability levels tend to be much higher than corresponding job demands, even at older 
ages. As a result, age-related decline in ability is not large enough to push many individuals below the thresholds required for many jobs.

Figure 4. Average work capacity by five-year age group

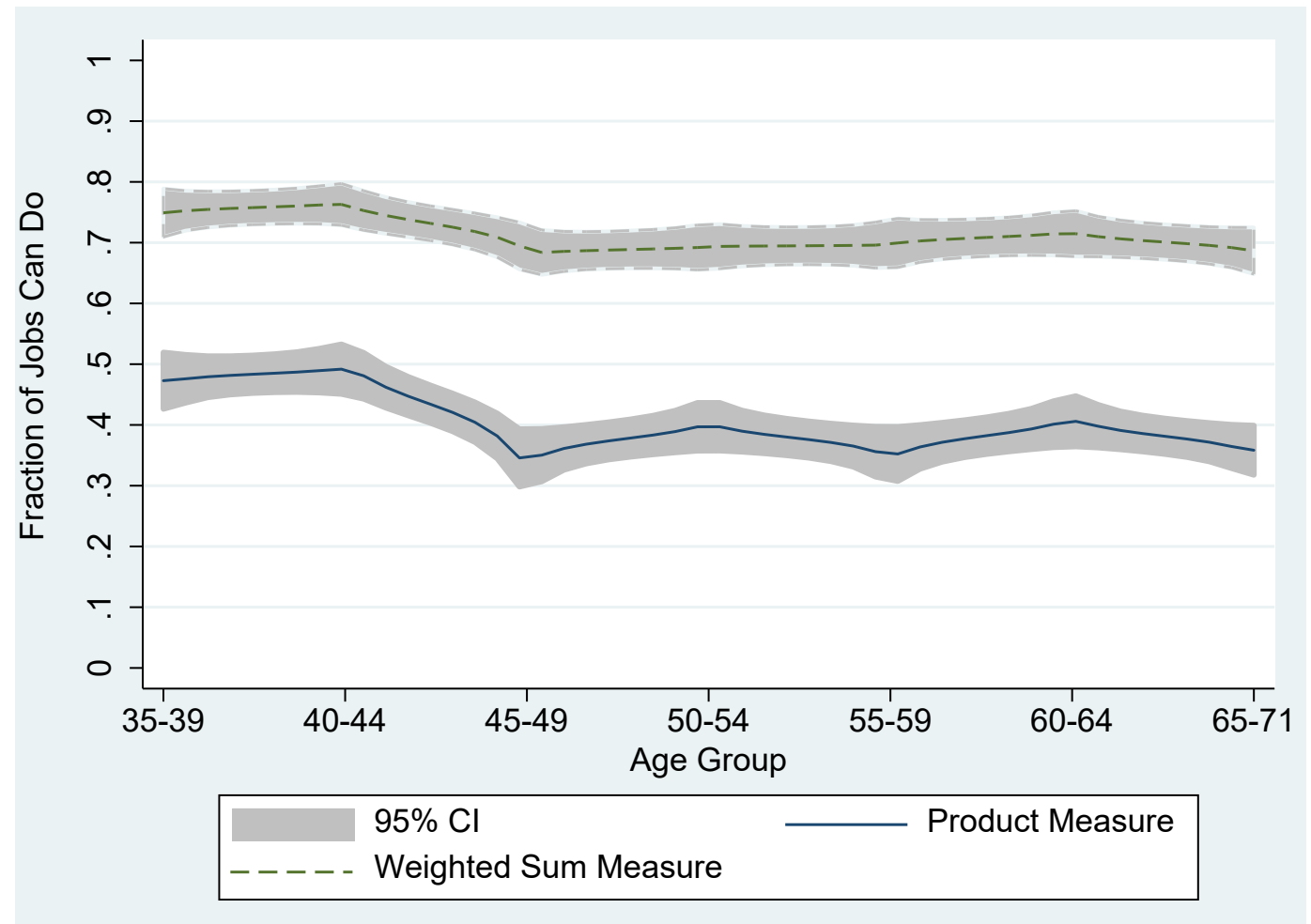

Finally, we are interested in understanding how much value is added by modeling work and retirement decisions using work capacity—which is uniquely driven by the intersection between individuals' abilities and corresponding job requirementscompared with using health alone (which is strongly correlated with individuals' abilities). Figure 5 presents average total work capacity by self-reported health status. For both measures, average total work capacity is statistically indistinguishable between individuals who rate their health "excellent" or "very good" and declines as health status falls from "good" to "fair" to "poor." Figure 6 shows average work capacity for individuals with and without self-reported, work-limiting health problems. In both cases, those with work-limiting health problems have significantly lower measured work capacity (around 
18 to 20 percentage points) than those without work-limiting health problems. At the same time, by both measures, individuals with work-limiting health problems can still do a substantial fraction of jobs for a given educational level, on average-27 percent according to the product measure and 56 percent according to the weighted sum measure.

Figure 5: Average work capacity by self-reported health status
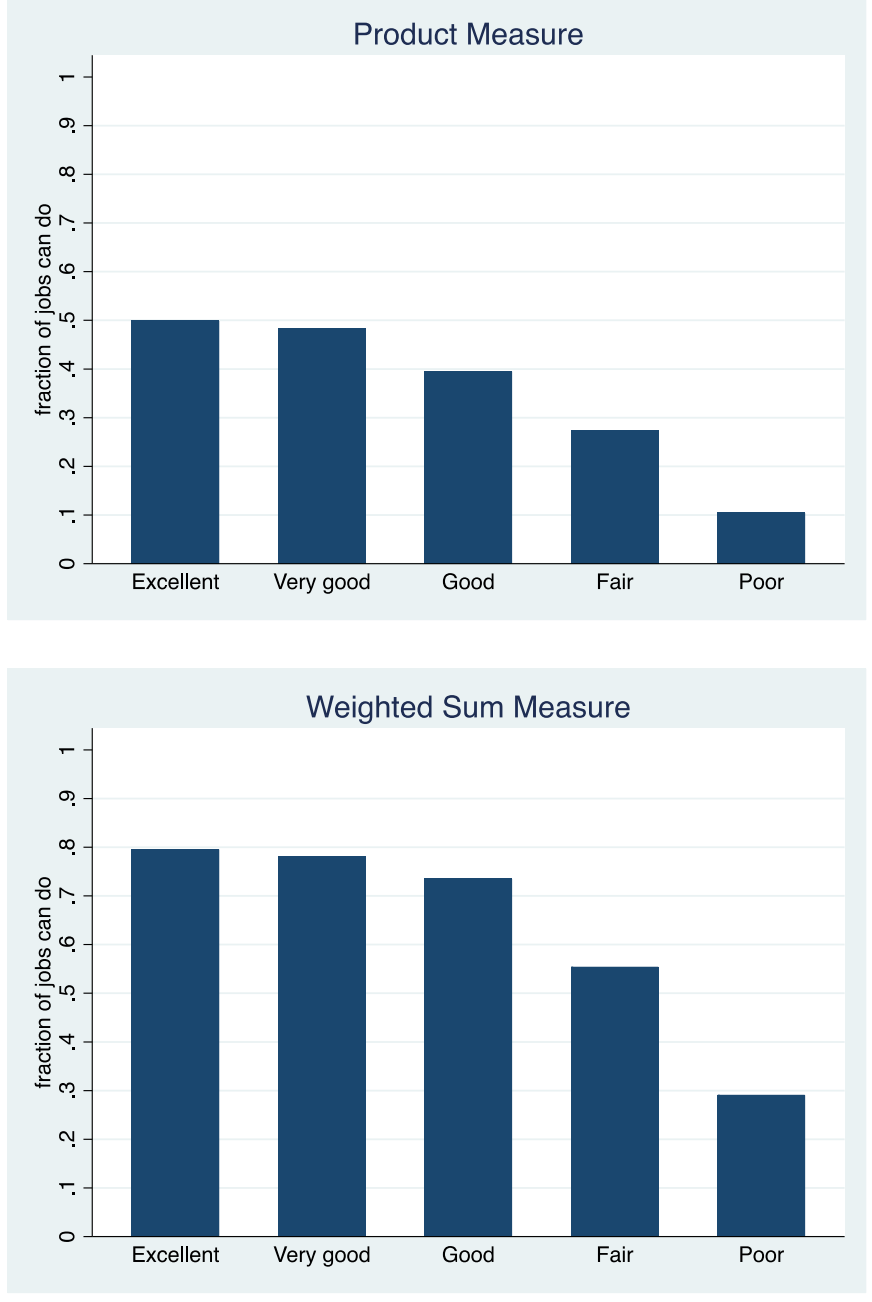
Figure 6: Average work capacity by work-limiting health problem status
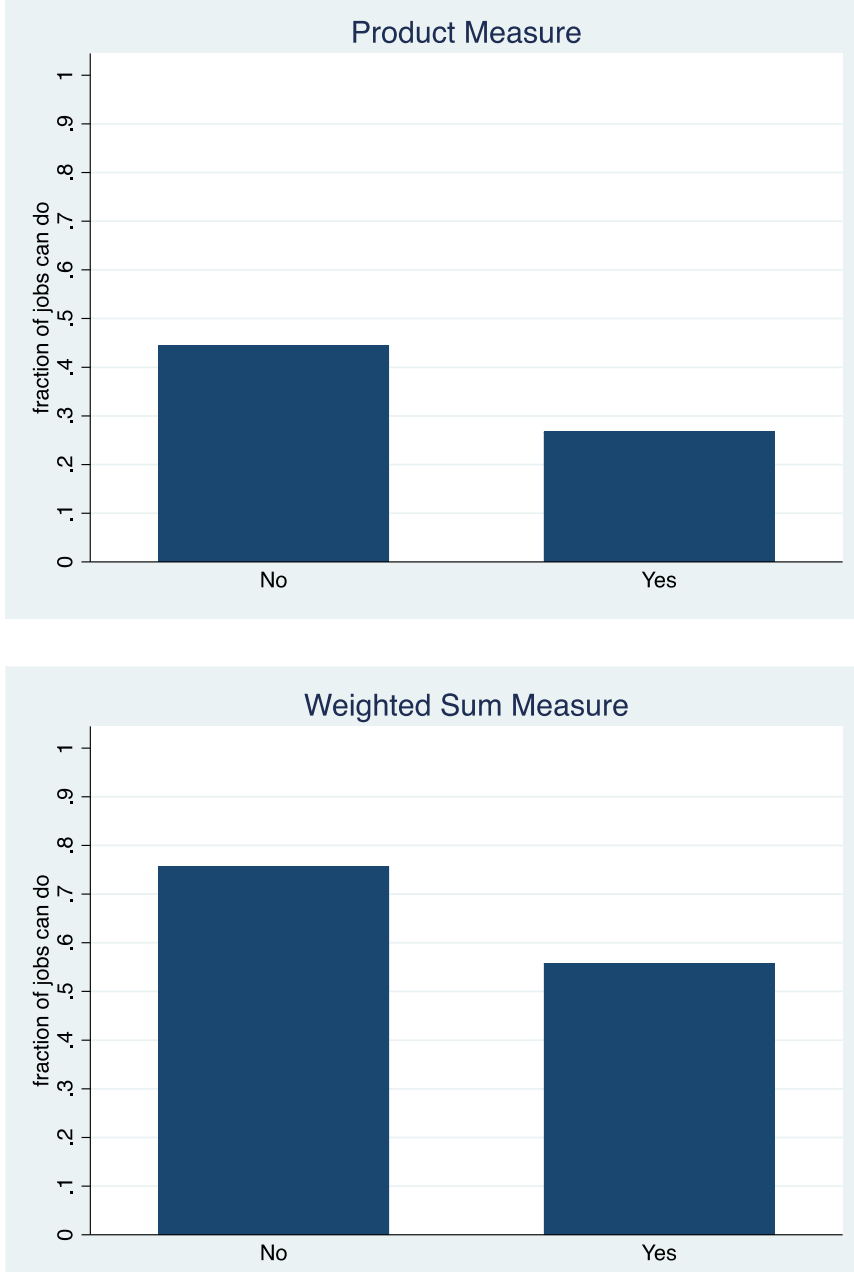

\section{Work capacity and current labor supply}

In this section, we investigate the extent to which work capacity, or the fraction of jobs individuals are able to do for a given educational level, relates to current labor force participation compared with standard measures of health status. We study two labor supply outcomes: an indicator variable for whether the individual is currently in the labor force (i.e., working for pay, unemployed, or on temporary layoff) and an indicator variable for whether the individual reports receiving Social Security Disability Insurance benefits. 


\subsection{Labor force participation}

We begin by investigating the effect of total work capacity on labor force participation (LFP), both in comparison to and in concert with the effects of conventional measures of health status. Table 4 presents three sets of regression specifications. The first set, reported in Columns 1 and 2, show coefficients of LFP regressions on the standard health variables, self-reported health status (with excellent/very good as the baseline category), and presence of a work-limiting health problem, respectively. In the second set (Columns 3 and 4 ) we regress LFP on our conservative measure of total work capacity, with and without additional controls for health. And in the third set (Columns 5-6), we report LFP regressions on our more generous weighted sum measure, with and without additional controls for health. Both measures of work capacity can be interpreted as the fraction of jobs for a given educational level that an individual can do based on their abilities relative to job demands. All regressions include controls for five-year age groups with ages 65 to 71 as the baseline category. That way, the constant term can be interpreted as the predicted labor force participation rate of a 65 to 71 year old when other explanatory variables are set to zero.

In Column 1, the labor force participation rate for an individual older than 65 in excellent or very good health is 34 percent (the constant term). There is little differential association between LFP and good health as compared to excellent/very good health. But being in fair/poor health is associated with a 30 percentage point LFP reduction, compared with being in excellent/very good health, implying a predicted labor force participation rate of just 4 percent for 65 to 70 year olds in fair/poor health. In Column 2, we perform the same exercise as in Column 1, but instead we use as our health measure an indicator variable for whether the individual reports having a work-limiting 
health problem. Having a work-limiting health problem is associated with a 36.5 percentage point reduction in labor force participation compared with not having a worklimiting health problem. Again, we find that a 65 to 71 year old with a work-limiting health problem has a predicted labor force participation rate of only 4 percent.

Columns 3 and 4 present results of LFP regressions on the product work capacity measure, with and without controlling for health. In Column 3, we estimate that the LFP rate of individuals ages 65 to 71 who are classified as unable to do any job for their educational level is 23 percent. Those classified as able to do 100 percent of jobs for their educational level are 14.6 percentage points more likely to work than those classified as unable to do any job - a 65 percent increase in labor force participation. Adding health controls in Column 4 reduces the coefficient on the size of the potential job set from 14.6 to 6.1 percentage points, reflecting the strong underlying (but imperfect) correlation between work capacity and health. However, work capacity remains a statistically significant, independent predictor of work status, even controlling for health.

In Columns 5 and 6 we perform the same analyses as in Columns 3 and 4 but with the weighted sum work capacity measure instead of the product measure. The constant term again reflects the predicted labor force participation rate of an individual age 65 to 71 classified as unable to do any job for a given educational level — in this case, 14 percent. A same-aged individual who is classified as able to do every job for a given educational level has a predicted labor force participation rate of 35 percent, 21 percentage points higher or more than double the LFP rate as someone unable to do (a substantial enough fraction) of any job. As before, controlling for health reduces the independent effect of work capacity (as it should, if functional capacity is fundamentally 
a health construct) to 9.8 percentage points, but even so, work capacity remains a strong predictor of labor force participation rates among older workers.

Overall, these results suggest that the two measures of work capacity do have statistically significant relationships with current LFP that reflect underlying health to an important degree but also contribute explanatory variation independent of health alone. The underlying source of the additional variation in the work capacity measures is the (mis)match between abilities and job demands. The magnitudes of these relationships are economically relevant compared with standard health variables.

Table 4: Regressions of labor force participation on health and fraction of jobs individuals can do

\begin{tabular}{|c|c|c|c|c|c|c|}
\hline \multirow[b]{2}{*}{$\begin{array}{l}\text { Dep. Var.: Working for } \\
\text { Pay }\end{array}$} & \multirow[b]{2}{*}{$\begin{array}{c}(1) \\
\text { coef/se }\end{array}$} & \multirow[b]{2}{*}{$\begin{array}{c}\text { (2) } \\
\text { coef/se }\end{array}$} & \multicolumn{2}{|c|}{$\begin{array}{c}\text { Product Work } \\
\text { Capacity Measure }\end{array}$} & \multicolumn{2}{|c|}{$\begin{array}{c}\text { Weighted Sum Work } \\
\text { Capacity Measure }\end{array}$} \\
\hline & & & $\begin{array}{c}(\mathbf{3}) \\
\text { coef/se }\end{array}$ & $\begin{array}{c}(4) \\
\text { coef/se }\end{array}$ & $\begin{array}{c}\mathbf{( 5 )} \\
\text { coef/se }\end{array}$ & $\begin{array}{c}\text { (6) } \\
\text { coef/se }\end{array}$ \\
\hline Fraction of jobs can do & & & $\begin{array}{l}0.146^{\star * *} \\
(0.025)\end{array}$ & $\begin{array}{l}0.061^{* *} \\
(0.024)\end{array}$ & $\begin{array}{c}0.209^{* * *} \\
(0.025)\end{array}$ & $\begin{array}{c}0.098^{* * *} \\
(0.025)\end{array}$ \\
\hline Health Status & & & & & & \\
\hline Good & $\begin{array}{c}0.010 \\
(0.019)\end{array}$ & & & $\begin{array}{l}0.053^{\star \star *} \\
(0.019)\end{array}$ & & $\begin{array}{l}0.051^{* * *} \\
(0.019)\end{array}$ \\
\hline Fair/Poor & $\begin{array}{c}-0.303^{\star \star *} \\
(0.025)\end{array}$ & & & $\begin{array}{l}-0.116^{* * \star} \\
(0.028)\end{array}$ & & $\begin{array}{c}-0.106^{\star * *} \\
(0.028)\end{array}$ \\
\hline $\begin{array}{l}\text { Has a work-limiting } \\
\text { health problem }\end{array}$ & & $\begin{array}{c}-0.365^{\star * *} \\
(0.021)\end{array}$ & & $\begin{array}{c}-0.298^{* * *} \\
(0.024)\end{array}$ & & $\begin{array}{c}-0.294^{* * *} \\
(0.024)\end{array}$ \\
\hline Constant & $\begin{array}{l}0.340^{\star * \star} \\
(0.024)\end{array}$ & $\begin{array}{c}0.409^{* * *} \\
(0.023)\end{array}$ & $\begin{array}{c}0.226^{* * *} \\
(0.025)\end{array}$ & $\begin{array}{l}0.372^{* * *} \\
(0.026)\end{array}$ & $\begin{array}{l}0.136^{\star \star *} \\
(0.029)\end{array}$ & $\begin{array}{l}0.323^{* * *} \\
(0.031)\end{array}$ \\
\hline Number of observations & 1,934 & 1,934 & 1,934 & 1,934 & 1,934 & 1,934 \\
\hline Adjusted R2 & 0.273 & 0.313 & 0.219 & 0.330 & 0.232 & 0.333 \\
\hline
\end{tabular}

Note: All regressions control for age groups with baseline category age 65-71. The omitted (baseline) category for self-reported health status is excellent/very good. Significance levels: 0.01 - $^{* * *} ; 0.05$ - $^{* *} ; 0.1$ - * $^{*}$ 


\subsection{Receiving Social Security Disability Insurance benefits}

Federal disability insurance benefits are intended to replace lost earnings due to health shocks that prevent individuals from performing their own or any other job in the national economy to any substantial degree. SSDI uses disability criteria that implicitly link an applicant's remaining work capacity to the (predominantly physical) requirements of occupations at their educational level. The goal is to assess whether the applicant's ability profile is transferable to other occupations with only a limited amount of retraining. Since our work capacity measure explicitly measures individuals' potential job prospects through the interaction of their health and occupational demands, it should both reflect underlying health and also add value over standard health measures in predicting SSDI receipt. Table 5 presents regression results examining this hypothesis. As in Table 4, we first present the associations of traditional health indicators with disability status, and then we add our measures of total work capacity to the analysis. All regressions include controls for five-year age groups, but here we set the youngest age group, ages 35 to 39 , as the omitted (baseline) category. That way, the constant term can be interpreted as the predicted SSDI receipt rate of a 35 to 39 year old when other explanatory variables are set to zero.

Column 1 shows that, as expected, statistically zero percent of individuals ages 35-39 with excellent or very good health claim SSDI benefits. Having good health does not change the percentage of SSDI recipients compared with being in excellent/very good health. And having fair/poor health status increases the percentage of SSDI recipients to 28 percent. Column 2 shows that statistically zero percent of individuals without a work-limiting health problem claim SSDI benefits, compared with 31 percent among those who do report having a health problem that limits their work ability. 
Columns 3 and 4 examine the role of work capacity using our product measure. In Column 3, the predicted rate of SSDI receipt among 35 to 39 year olds classified as unable to do any job for their educational level is 10 percent. Being classified as able to do any job for a given educational level reduces the predicted SSDI receipt to essentially zero. When we include work capacity and standard health measures in the same regression, both self-reported health status and presence of a work-limiting health problem remain predictive but the product work capacity measure no longer has a statistically significant association with SSDI receipt. This suggests that the main channel through which this work capacity measure relates to SSDI receipt is the variation in standard health status measures relevant for determining SSDI qualification.

Finally, Columns 5 and 6 repeat the same analysis using instead the weighted sum work capacity measure. In this case, 35 to 39 year olds classified as unable to do any job for their educational level have an 18 percent probability of receiving SSDI benefits, twice as high as the rate classified as unable to work using the product measure. As before, an increase in the size of the potential job set from being unable to do any job to being able to do any job at a given educational level essentially eliminates one's chances of receiving SSDI. Moreover, when we add controls for health (Column 6), the weighted sum work capacity measure remains a statistically significant predictor of SSDI receipt, suggesting that it includes additional information about the probability of SSDI receipt beyond standard health measures alone. 
Table 5: Regressions of SSDI receipt on the fraction of jobs Individuals can do

\begin{tabular}{|c|c|c|c|c|c|c|}
\hline \multirow[b]{2}{*}{ Dep. Var.: SSDI receipt } & \multicolumn{2}{|c|}{ Only Health } & \multicolumn{2}{|c|}{ Product Measure } & \multicolumn{2}{|c|}{$\begin{array}{c}\text { Weighted Sum } \\
\text { Measure }\end{array}$} \\
\hline & $\begin{array}{c}(1) \\
\text { coef/se }\end{array}$ & $\begin{array}{c}(2) \\
\text { coef/se }\end{array}$ & $\begin{array}{c}(3) \\
\text { coef/se }\end{array}$ & $\begin{array}{c}(4) \\
\text { coef/se }\end{array}$ & $\begin{array}{c}(5) \\
\text { coef/se }\end{array}$ & $\begin{array}{c}(6) \\
\text { coef/se }\end{array}$ \\
\hline $\begin{array}{l}\text { Fraction of jobs can } \\
\text { do }\end{array}$ & & & $\begin{array}{l}-0.101^{* * *} \\
(0.018)\end{array}$ & $\begin{array}{l}-0.027 \\
(0.017)\end{array}$ & $\begin{array}{c}-0.174^{* * *} \\
(0.018)\end{array}$ & $\begin{array}{r}-0.080^{* * *} \\
(0.017)\end{array}$ \\
\hline \multicolumn{7}{|l|}{ Health Status } \\
\hline Good & $\begin{array}{c}0.011 \\
(0.014)\end{array}$ & & & $\begin{array}{l}-0.021 \\
(0.013)\end{array}$ & & $\begin{array}{l}-0.022^{*} \\
(0.013)\end{array}$ \\
\hline Fair/Poor & $\begin{array}{l}0.263^{* * *} \\
(0.027)\end{array}$ & & & $\begin{array}{l}0.118^{* * *} \\
(0.028)\end{array}$ & & $\begin{array}{c}0.105^{\star * *} \\
(0.028)\end{array}$ \\
\hline $\begin{array}{l}\text { Has a work-limiting } \\
\text { health problem }\end{array}$ & & $\begin{array}{l}0.299 * * * \\
(0.015)\end{array}$ & & $\begin{array}{l}0.238^{* * *} \\
(0.017)\end{array}$ & & $\begin{array}{c}0.233^{* * *} \\
(0.017)\end{array}$ \\
\hline Constant & $\begin{array}{c}0.021 \\
(0.019)\end{array}$ & $\begin{array}{c}0.016 \\
(0.017)\end{array}$ & $\begin{array}{l}0.098^{* * *} \\
(0.020)\end{array}$ & $\begin{array}{l}0.035^{*} \\
(0.020)\end{array}$ & $\begin{array}{l}0.180^{* * *} \\
(0.023)\end{array}$ & $\begin{array}{c}0.085^{* * *} \\
(0.023)\end{array}$ \\
\hline $\begin{array}{l}\text { Number of } \\
\text { observations }\end{array}$ & 1,925 & 1,925 & 1,925 & 1,925 & 1,925 & 1,925 \\
\hline Adjusted R2 & 0.126 & 0.184 & 0.028 & 0.208 & 0.056 & 0.216 \\
\hline
\end{tabular}

Note: All regressions control for age groups with base category ages 35-39 The omitted (baseline) category for self-reported health status is excellent/very good. Significance levels: $0.01-^{* * *} ; 0.05-^{* *} ; 0.1-^{*}$

\section{Work capacity and retirement expectations}

We now turn to analyzing the relationship between work capacity and future labor supply decisions by studying two outcomes. First, we look at the subjective probability of working longer among individuals who are currently in the labor force. We do so by pooling together the subsample of workers younger than 65 that reported subjective probabilities of working past age 65 and the subsample of workers between 65 and 71 that reported subjective probabilities of working past age 70 . Second, we study the subjective probability of returning to the labor force separately for individuals that report their current labor supply status as retired or disabled. 


\subsection{Working longer}

Table 6 presents results of regressions of the probability of working longer (past age 65 for those younger than 65 and past age 70 for those in the 65 -to-71 age range) on health and work capacity measures, separately and together. As in Table 4 above, we let age 65 to 71 be the omitted (baseline) category for the age group controls so the constant term can be interpreted as the predicted subjective probability of working longer for a 65 to 71 year old when other explanatory variables are set to zero. Column 1 shows that the expectation of working longer of a 65 - to 71 -yearold individual with excellent or very good health is 56 percent. Having good health, instead, would reduce the expectation of working longer by 5 percentage points, and having fair or poor health does not have a differential association with the expectation of working longer. Column 2 shows that having a work-limiting health problem does not correlate significantly with expectations of working longer.

In Columns 3 to 6 we observe that both work capacity measures are strongly correlated with the self-reported probability of working longer over and above the associations between standard measures of health and expectations of working longer. An increase in the size of the potential job set from being able to do any job to being able to do all jobs at a given educational level according to the product measure is associated with a 6.6 percentage point increase in the subjective probability of working longer. This represents a 12.8 percent increase over the baseline average probability of 51 percent among the 65- to 71-year-old-age group. Controlling for standard measures of health decreases the effect of the product work capacity measure only slightly, to 6.1 percentage points. The weighted sum work capacity measure is even more predictive of subjective expectations for working longer. An increase from 0 to 1 in the size of the potential job set using the weighted sum measure increases the subjective probability of working longer by 10.4 percentage points, a 23 percent increase in the baseline probability of working longer. The coefficient on the weighted sum work capacity measure is also unchanged when standard health variables are included as controls. 
Overall, our results suggest that our measures of work capacity based on the intersection between abilities and job demands for a given educational level are predictive of individuals' expectations about the timing of retirement beyond the variation in these expectations associated with standard health measures.

Table 6: Regressions of subjective probability of working past age 65 or past age 70 on the fraction of jobs individuals can do

\begin{tabular}{|c|c|c|c|c|c|c|}
\hline \multirow[b]{2}{*}{$\begin{array}{l}\text { Dep. Var.: Probability } \\
\text { of working past age } \\
65 \text { or } 70 \text { ) }\end{array}$} & \multicolumn{2}{|c|}{ Only health } & \multicolumn{2}{|c|}{$\begin{array}{c}\text { Product-based } \\
\text { Measure }\end{array}$} & \multicolumn{2}{|c|}{ Weighted Sum Measure } \\
\hline & $\begin{array}{c}\text { (1) } \\
\text { coef/se }\end{array}$ & $\begin{array}{c}(2) \\
\text { coef/se }\end{array}$ & $\begin{array}{c}(3) \\
\text { coef/se }\end{array}$ & $\begin{array}{c}\text { (4) } \\
\text { coef/se }\end{array}$ & $\begin{array}{c}\text { (5) } \\
\text { coef/se }\end{array}$ & $\begin{array}{c}(6) \\
\text { coef/se }\end{array}$ \\
\hline $\begin{array}{l}\text { Fraction of jobs can } \\
\text { do }\end{array}$ & & & $\begin{array}{l}0.066^{* * *} \\
(0.023)\end{array}$ & $\begin{array}{l}0.061^{* *} \\
(0.024)\end{array}$ & $\begin{array}{l}0.104^{* * *} \\
(0.026)\end{array}$ & $\begin{array}{l}0.103^{* * *} \\
(0.026)\end{array}$ \\
\hline \multicolumn{7}{|l|}{ Health Status } \\
\hline Good & $\begin{array}{c}-0.052^{* * *} \\
(0.018)\end{array}$ & & & $\begin{array}{l}-0.046^{* *} \\
(0.019)\end{array}$ & & $\begin{array}{c}-0.049^{* * *} \\
(0.018)\end{array}$ \\
\hline Fair/Poor & $\begin{array}{l}-0.012 \\
(0.029)\end{array}$ & & & $\begin{array}{l}-0.004 \\
(0.030)\end{array}$ & & $\begin{array}{l}-0.002 \\
(0.030)\end{array}$ \\
\hline $\begin{array}{l}\text { Has a work-limiting } \\
\text { health problem }\end{array}$ & & $\begin{array}{l}-0.002 \\
(0.027)\end{array}$ & & $\begin{array}{l}0.010 \\
(0.028)\end{array}$ & & $\begin{array}{l}0.010 \\
(0.028)\end{array}$ \\
\hline Constant & $\begin{array}{l}0.562^{* * *} \\
(0.036)\end{array}$ & $\begin{array}{l}0.542^{* * *} \\
(0.035)\end{array}$ & $\begin{array}{l}0.514^{* * *} \\
(0.036)\end{array}$ & $\begin{array}{l}0.532^{* * *} \\
(0.038)\end{array}$ & $\begin{array}{l}0.461^{* * *} \\
(0.040)\end{array}$ & $\begin{array}{l}0.478^{* * *} \\
(0.042)\end{array}$ \\
\hline $\begin{array}{l}\text { Number of } \\
\text { observations }\end{array}$ & 1,296 & 1,296 & 1,296 & 1,296 & 1,296 & 1,296 \\
\hline Adjusted R2 & 0.012 & 0.007 & 0.013 & 0.016 & 0.019 & 0.023 \\
\hline
\end{tabular}

Note: All regressions control for age groups with base category age 65-71. The omitted (baseline) category for self-reported health status is excellent/very good. Significance levels: $0.01{ }^{* * *} ; 0.05-{ }^{* *} ; 0.1-^{*}$ 


\subsection{Unretirement}

Finally, we are interested not just in exits from the labor force but also in potential reentry. Table 7 presents probability of returning to the labor force regression results among individuals who report that they are retired. For this analysis, we dropped three respondents younger than 50 who reported themselves as retired. As in Tables 4 and 6 above, we let age 65 to 71 be the omitted (baseline) category for the age group controls so the constant term can be interpreted as the predicted subjective probability of working longer for a 65 to 71 year old with other explanatory variables set to zero. In Column 1, we see that the average reported probability of "unretirement" is 21 percent among those ages 65 to 71 who report excellent or very good health. This probability is statistically the same for same-aged individuals in good and fair or poor health. But Column 2 shows that the presence of a work-limiting health problem reduces unretirement probability by a marginally statistically significant 5 percentage points $(p<0.1)$.

In Column 3, we see that the product work capacity measure is strongly predictive of expected unretirement. Whereas a 65 to 71 year old classified as unable to do any job for his education reports an average unretirement probability of 16 percent, the same individual classified as able to do any job for his education nearly doubles his average unretirement probability to 27 percent. Adding controls for health only slightly reduces the association between the conservative product work capacity measure and the subjective probability of unretirement (Column 4). Columns 5 to 6 show that the weighted sum work capacity measure is also predictive of unretirement independent of standard health measures, but the increase in the expectation of unretirement associated with an increase in the set of potential jobs (from none to all jobs) is smaller 
than that obtained using the product measure; 8.7 percentage points without controlling for health, and 7.8 percentage points controlling for health.

Table 7: Regressions of subjective probability of returning to work from retirement on the fraction of jobs individuals can do

\begin{tabular}{|c|c|c|c|c|c|c|}
\hline \multirow[b]{2}{*}{$\begin{array}{l}\text { Dep. Var.: Probability of } \\
\text { returning to the labor force }\end{array}$} & \multicolumn{2}{|c|}{ Only Health } & \multicolumn{2}{|c|}{ Product Measure } & \multicolumn{2}{|c|}{$\begin{array}{l}\text { Weighted Sum } \\
\text { Measure }\end{array}$} \\
\hline & $\begin{array}{c}\text { (1) } \\
\text { coef/se }\end{array}$ & $\begin{array}{c}(2) \\
\text { coef/se }\end{array}$ & $\begin{array}{c}\text { (3) } \\
\text { coef/se }\end{array}$ & $\begin{array}{c}(4) \\
\text { coef/se }\end{array}$ & $\begin{array}{c}(5) \\
\text { coef/se }\end{array}$ & $\begin{array}{c}(6) \\
\text { coef/se }\end{array}$ \\
\hline Fraction of jobs can do & & & $\begin{array}{l}0.117^{\star \star *} \\
(0.038)\end{array}$ & $\begin{array}{c}0.107^{* * *} \\
(0.039)\end{array}$ & $\begin{array}{l}0.087^{* *} \\
(0.038)\end{array}$ & $\begin{array}{l}0.078^{*} \\
(0.041)\end{array}$ \\
\hline Health Status & & & & & & \\
\hline Good & $\begin{array}{l}-0.018 \\
(0.032)\end{array}$ & & & $\begin{array}{l}-0.003 \\
(0.033)\end{array}$ & & $\begin{array}{l}-0.004 \\
(0.033)\end{array}$ \\
\hline Fair/Poor & $\begin{array}{l}-0.053 \\
(0.035)\end{array}$ & & & $\begin{array}{l}-0.004 \\
(0.044)\end{array}$ & & $\begin{array}{l}-0.001 \\
(0.045)\end{array}$ \\
\hline $\begin{array}{l}\text { Has a work-limiting health } \\
\text { problem }\end{array}$ & & $\begin{array}{l}-0.049^{*} \\
(0.028)\end{array}$ & & $\begin{array}{l}-0.032 \\
(0.035)\end{array}$ & & $\begin{array}{l}-0.039 \\
(0.035)\end{array}$ \\
\hline Constant & $\begin{array}{c}0.213^{\star * *} \\
(0.021) \\
\end{array}$ & $\begin{array}{l}0.215^{\star * *} \\
(0.020)\end{array}$ & $\begin{array}{l}0.156^{* * *} \\
(0.021)\end{array}$ & $\begin{array}{l}0.174^{\star * *} \\
(0.027)\end{array}$ & $\begin{array}{c}0.139^{* * *} \\
(0.030)\end{array}$ & $\begin{array}{c}0.161^{* * *} \\
(0.037)\end{array}$ \\
\hline Number of observations & 387 & 387 & 387 & 387 & 387 & 387 \\
\hline Adjusted R2 & 0.005 & 0.010 & 0.026 & 0.022 & 0.015 & 0.012 \\
\hline
\end{tabular}

Note: All regressions control for age groups with base category age 65-71. The omitted (baseline) category for self-reported health status is excellent/very good. Significance levels: $0.01-^{* * *} ; 0.05-^{* *} ; 0.1-^{*}$

Finally, Table 8 present results from similar regressions as in Table 7 but conditional on the subsample of those who report their current labor status as disabled. Column 1 shows that the average probability of returning to the labor force among disabled individuals ages 35 to 39 who nevertheless report they are in excellent or very 
good health is 71 percent, ${ }^{14}$ and while this probability does not change statistically for those who report to be in good health, it decreases by 35 percentage points for those reporting fair or poor health. In Column 2, we see that the average self-reported probability of returning to the labor force among individuals who nevertheless report they do not have a work-limiting health problem is 92 percent, and among those reporting a work-limiting health problem is 48 percent-still relatively high for this population, considering that 83 percent of these individuals are currently receiving SSDI benefits. Returning to the labor force among SSDI beneficiaries is known to be very low, although rising in recent years along with employment among people with disabilities (Maestas forthcoming).

Our work capacity measures are about twice as predictive for return to work from disability status as they are for unretirement. Using the product measure, in Column 3 we observe that going from 0 to 1 in the fraction of jobs that an individual can do for their education increases the subjective probability of returning to the labor force by 25 percentage points, or about 50 percent over the baseline subjective probability for a 35 to 39 year old. Adding health controls reduces the association between work capacity and the probability of returning to the labor force, and it is no longer statistically significant, though the sample size for these regressions is small (Column 4). The same pattern is apparent for the weighted sum measure (Column 6).

Note that, except for labor force participation, the previous outcomes largely reflect the exit margin of work, whereas the unretirement probability — whether from retirement or disability status - largely reflects the (re)entry margin. In the former case,

\footnotetext{
${ }^{14}$ Only $6 \%$ of individuals who report themselves disabled also report to be in excellent or very good health.
} 
the weighted sum measure was more predictive than the product measure; in the case of unretirement, the product measure is more predictive than the weighted sum measure. This suggests that the more conservative product measure, which requires abilities to meet or exceed all of the important occupational ability requirements, is relatively informative of job prospects on the hiring margin, where it may be more important for an applicant to demonstrate qualification on all job requirements. In contrast, the more generous weighted sum measure, which gives partial credit for occupational requirements mostly (though not fully) met, may be relatively informative about the exit margin. It is likely that job incumbents may have more scope for compensating for any ability losses, by drawing on skills and experience, by using assistive technologies, or by obtaining work modifications or other accommodations from their employers.

Table 8: Regressions of subjective probability of returning to work from disability on the fraction of jobs individuals can do

\begin{tabular}{|c|c|c|c|c|c|c|}
\hline \multirow[b]{2}{*}{$\begin{array}{l}\text { Dep. Var.: Probability } \\
\text { of returning to work }\end{array}$} & \multicolumn{2}{|c|}{ Only Health } & \multicolumn{2}{|c|}{ Product Measure } & \multicolumn{2}{|c|}{$\begin{array}{c}\text { Weighted Sum } \\
\text { Measure }\end{array}$} \\
\hline & $\begin{array}{c}\text { (1) } \\
\text { coef/se }\end{array}$ & $\begin{array}{c}(2) \\
\text { coef/se }\end{array}$ & $\begin{array}{c}\text { (3) } \\
\text { coef/se }\end{array}$ & $\begin{array}{c}(4) \\
\text { coef/se }\end{array}$ & $\begin{array}{c}\text { (5) } \\
\text { coef/se }\end{array}$ & $\begin{array}{c}\text { (6) } \\
\text { coef/se }\end{array}$ \\
\hline Fraction of jobs can do & & & $\begin{array}{l}0.248^{* * *} \\
(0.070)\end{array}$ & $\begin{array}{c}0.057 \\
(0.070)\end{array}$ & $\begin{array}{l}0.172^{* * *} \\
(0.054)\end{array}$ & $\begin{array}{c}0.077 \\
(0.051)\end{array}$ \\
\hline Health Status & & & & & & \\
\hline Fair & $\begin{array}{l}-0.121 \\
(0.093)\end{array}$ & & & $\begin{array}{l}-0.140 \\
(0.089)\end{array}$ & & $\begin{array}{l}-0.138 \\
(0.088)\end{array}$ \\
\hline Poor & $\begin{array}{c}-0.346^{* * *} \\
(0.083)\end{array}$ & & & $\begin{array}{c}-0.286^{* * *} \\
(0.082)\end{array}$ & & $\begin{array}{c}-0.279 * * * \\
(0.081)\end{array}$ \\
\hline $\begin{array}{l}\text { Has a work-limiting } \\
\text { health problem }\end{array}$ & & $\begin{array}{c}-0.438^{* * *} \\
(0.082)\end{array}$ & & $\begin{array}{c}-0.320^{* * *} \\
(0.085)\end{array}$ & & $\begin{array}{c}-0.326^{* * *} \\
(0.082)\end{array}$ \\
\hline Constant & $\begin{array}{l}0.713^{* * *} \\
(0.097)\end{array}$ & $\begin{array}{l}0.917^{* * *} \\
(0.110)\end{array}$ & $\begin{array}{l}0.502^{* * *} \\
(0.082)\end{array}$ & $\begin{array}{l}0.981^{* * *} \\
(0.122)\end{array}$ & $\begin{array}{l}0.488^{* * *} \\
(0.083)\end{array}$ & $\begin{array}{l}0.974^{* * *} \\
(0.119)\end{array}$ \\
\hline
\end{tabular}




\begin{tabular}{l|rc|cc|cc}
\hline $\begin{array}{l}\text { Number of } \\
\text { observations }\end{array}$ & 157 & 157 & 157 & 157 & 157 & 157 \\
Adjusted R2 & 0.366 & 0.355 & 0.293 & 0.426 & 0.282 & 0.432 \\
\hline \hline
\end{tabular}

Note: All regressions control for age groups with base category age 35-39. The omitted (baseline) category for self-reported health status is excellent/very good. Significance levels: $0.01-^{* * *} ; 0.05$ - $^{* *} ; 0.1$ - * $^{*}$

\section{Conclusion}

Declining health with age can limit individuals' work capacity, increasing the likelihood of mismatch between their abilities to perform certain tasks and the minimum demands of available jobs them. Traditional health status measures are insufficient for understanding how labor force participation and retirement intentions are influenced by the match between individuals' abilities and job demands.

In this paper, we use new survey data harmonized with the O*NET database to create a new measure of individual work capacity, defined as the share of all occupations for a given educational level that the individual can do, and that is based on comparisons between individuals' own ability levels and the minimum levels required to perform a given occupation across 52 different abilities and for nearly 800 occupations. We use this information to construct a one-dimensional summary measure of individuals' work capacity that we hypothesize is predictive of current labor force participation decisions, as well as of subjective expectations about the timing of retirement and about returning to the labor force among individuals who are retired or disabled.

Our results can be summarized in three findings. First, we find that average abilities overall and across different domains are high relative to average occupational demands. Second, age-related declines in abilities are modest. Putting these elements 
together, individuals' work capacity is relatively stable with age. Third, our work capacity measures are predictive of current labor supply outcomes. An increase in work capacity from being unable to do any job to being able to do all jobs given the individual's educational level is significantly associated with a 15 to 21 percentage point increase in labor force participation and a 10 to 17 percentage point decrease in the percentage of recipients of Social Security Disability benefits. Work capacity is also predictive of subjective expectations about future labor force participation decisions. An increase in individual's work capacity from being unable to do any job to being able to do all job given the educational level is associated with a 7 to 10 percentage point increase in chance that current workers will work past age 65 or 70 (depending on the individual's age), a 9 to 12 percentage point increase in the chance that retired individuals will return to the labor force, and a 17 to 25 percentage point increase in the chance that individuals with disabilities will return to the labor force.

Since these associations are significant over and above the associations between outcomes and health and are all economically relevant, we conclude that a work capacity measure based on the (mis)match between a comprehensive set of abilities and job demands can increase understanding of labor force outcomes at older ages and inform the design of policies affecting the length of individuals' working lives. 


\section{References}

Belbase, Anek, Geoffrey Sanzenbacher, and Christopher M Gillis. 2015. "Does AgeRelated Decline in Ability Correspond with Retirement Age?" Center for Retirement Research at Boston College Working Paper. (2015-24).

Börsch-Supan, Axel, and Matthias Weiss. 2016. "Productivity and Age: Evidence from Work Teams at the Assembly Line." The Journal of the Economics of Ageing 7: $30-42$.

Burtless, Gary. 2013. "The Impact of Population Aging and Delayed Retirement on Workforce Productivity." Available at SSRN 2275023.

Coile, Courtney, Kevin Milligan, and David A. Wise. 2017. "Health capacity to work at older ages: evidence from the United States." In Social Security Programs and Retirement around the World: The Capacity to Work at Older Ages, ed. David A. Wise, 359-394. University of Chicago Press.

Cutler, David M., Ellen Meara, Wilson F. Powell, and Seth Richards-Shubik. 2014. "Health and work capacity of older adults: Estimates and implications for social security policy." SSRN.

Fleisher, Matthew S, Suzanne Tsacoumis. 2012. "O*NET Analyst Occupational Abilities Ratings: Procedures Update." Alexandria, VA: Human Resources Research Organization.

Fleishman, Edwin A., David P. Costanza, and Joanne Marshall-Mies. 1999. "Abilities." In An occupational information system for the 21st century: The development of $O^{*} N E T$, eds. Norman G. Peterson, Michael D. Mumford, Walter C. Borman, Richard P. Jeanneret, and Edwin A. Fleishman, 175-195. Washington, D.C: American Psychological Association.

Gruber, Jonathan, and David Wise. 2004. "Social Security Programs around the World: Micro Estimation." 
Hudomiet, Péter, Michael D. Hurd, Susann Rohwedder, and Robert J Willis. 2017. "The Effect of Physical and Cognitive Decline at Older Ages on Work and Retirement: Evidence from Occupational Job Demands and Job Mismatch."

Hurd, Michael D. 2009. "Subjective Probabilities in Household Surveys." Annual Review of Economics 1(1): 543-562.

Lopez Garcia, Italo, Nicole Maestas and Kathleen J. Mullen. 2019. "Measuring Work Capacity." Working Paper.

Maestas, Nicole. Forthcoming. "Identifying Work Capacity and Promoting Work: A Strategy for Modernizing the SSDI Program." The ANNALS of the American Academy of Political and Social Science.

Maestas, Nicole, Kathleen J. Mullen, and David Powell. 2016. "The effect of population aging on economic growth, the labor force and productivity." NBER Working Paper Series no. w22452. National Bureau of Economic Research.

McGarry, Kathleen. 2004. "Health and Retirement Do Changes in Health Affect Retirement Expectations?" Journal of Human Resources 39(3): 624-48.

O*NET Resource Center. 2017. "Content Model Reference." National Center for O*NET Development. Available from https://www.onetcenter.org/dictionary/22.1/excel/content model reference.html.

Tsacoumis, Suzanne, Shannon Willison. 2010. "O*NET Analyst Occupational Skill Ratings: Procedures." Alexandria, VA: Human Resources Research Organization.

U.S. Census Bureau. 2018. Projected Age Groups and Sex Composition of the Population: Main Projections Series for the United States, 2017-2060. Washington, D.C: U.S. Census Bureau, Population Division.

Vaupel, James W. 2010. "Biodemography of human ageing." Nature 464(7288): 536542. 
Wilkinson, Richard, and Michael Marmot, eds. 2003. The Social Determinants of Health:

The Solid Facts, 2nd ed. Copenhagen, Denmark: World Health

Organization Europe. 


\title{
Appendix Figure 1. Screenshot from American Work Capacity and Activities Survey
}

\author{
Instructions for Rating Your Abilities
}

\begin{abstract}
In this survey, you will be asked to rate your level of functioning for a series of different abilities. When giving your rating, please rate your current level of ability, not what you were able to do in the past or what you could do in the future with additional training. If you use an assistive device (e.g., glasses), please rate your ability when using the assistive device.

First you will be shown the name and definition of an ability. Please read the definition carefully. For example:

\section{Arm-Hand Steadiness}

The ability to keep your hand and arm steady while moving your arm or while holding your arm and hand in one position.
\end{abstract}

You will then be asked to rate your level of ability on a scale from 1 to 7 , where 1 is the lowest possible level and 7 is the highest possible level. If you cannot do any level of the ability. please select that response below the numeric scale. To help you understand what we mean by level, we provide you with examples of tasks or activities at different levels for each ability. The examples are meant to help you find your own rating within the scale; do not focus on whether you perform the specific activity, which may come from an unfamiliar context. For examp

Please rate your level of ARM-HAND STEADINESS by clicking the circled number that best matches your level of ability. If you cannot do any level of the ability, please select the response below the number scale instead of clicking a circled number.

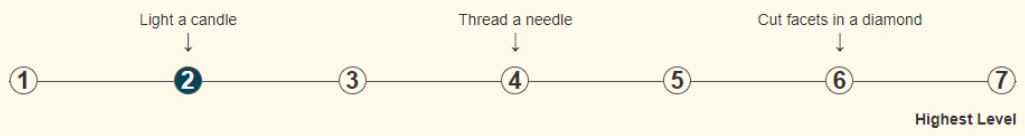

I cannot do any level of this ability 


\section{Appendix Table 1. Definition of O*NET abilities}

\begin{tabular}{|c|c|c|}
\hline \multicolumn{2}{|c|}{ Ability } & \multirow[t]{2}{*}{ Description } \\
\hline $\operatorname{Cog}$ & Jnitive Abilities & \\
\hline 1 & Oral Comprehension & $\begin{array}{l}\text { The ability to listen to and understand information and } \\
\text { ideas presented through spoken words and sentences. }\end{array}$ \\
\hline 2 & Written Comprehension & $\begin{array}{l}\text { The ability to read and understand information and ideas } \\
\text { presented in writing. }\end{array}$ \\
\hline 3 & Oral Expression & $\begin{array}{l}\text { The ability to communicate information and ideas in } \\
\text { speaking so others will understand. }\end{array}$ \\
\hline 4 & Written Expression & $\begin{array}{l}\text { The ability to communicate information and ideas in writing } \\
\text { so others will understand. }\end{array}$ \\
\hline 5 & Fluency of Ideas & $\begin{array}{l}\text { The ability to come up with a number of ideas about a topic } \\
\text { (the number of ideas is important, not their quality, } \\
\text { correctness, or creativity). }\end{array}$ \\
\hline 6 & Originality & $\begin{array}{l}\text { The ability to come up with unusual or clever ideas about a } \\
\text { given topic or situation, or to develop creative ways to solve } \\
\text { a problem. }\end{array}$ \\
\hline 7 & Problem Sensitivity & $\begin{array}{l}\text { The ability to tell when something is wrong or is likely to go } \\
\text { wrong. It does not involve solving the problem, only } \\
\text { recognizing there is a problem. }\end{array}$ \\
\hline 8 & Deductive Reasoning & $\begin{array}{l}\text { The ability to apply general rules to specific problems to } \\
\text { produce answers that make sense. }\end{array}$ \\
\hline 9 & Inductive Reasoning & $\begin{array}{l}\text { The ability to combine pieces of information to form general } \\
\text { rules or conclusions (includes finding a relationship among } \\
\text { seemingly unrelated events). }\end{array}$ \\
\hline 10 & Information Ordering & $\begin{array}{l}\text { The ability to arrange things or actions in a certain order or } \\
\text { pattern according to a specific rule or set of rules (e.g., } \\
\text { patterns of numbers, letters, words, pictures, mathematical } \\
\text { operations). }\end{array}$ \\
\hline 11 & Category Flexibility & $\begin{array}{l}\text { The ability to generate or use different sets of rules for } \\
\text { combining or grouping things in different ways. }\end{array}$ \\
\hline 12 & Mathematical Reasoning & $\begin{array}{l}\text { The ability to choose the right mathematical methods or } \\
\text { formulas to solve a problem. }\end{array}$ \\
\hline 13 & Number Facility & $\begin{array}{l}\text { The ability to add, subtract, multiply, or divide quickly and } \\
\text { correctly. }\end{array}$ \\
\hline 14 & Memorization & $\begin{array}{l}\text { The ability to remember information such as words, } \\
\text { numbers, pictures, and procedures. }\end{array}$ \\
\hline 15 & Speed of Closure & $\begin{array}{l}\text { The ability to quickly make sense of, combine, and } \\
\text { organize information into meaningful patterns. }\end{array}$ \\
\hline 16 & Flexibility of Closure & $\begin{array}{l}\text { The ability to identify or detect a known pattern (a figure, } \\
\text { object, word, or sound) that is hidden in other distracting } \\
\text { material. }\end{array}$ \\
\hline 17 & Perceptual Speed & $\begin{array}{l}\text { The ability to quickly and accurately compare similarities } \\
\text { and differences among sets of letters, numbers, objects, } \\
\text { pictures, or patterns. The things to be compared may be } \\
\text { presented at the same time or one after the other. This } \\
\text { ability also includes comparing a presented object with a } \\
\text { remembered object. }\end{array}$ \\
\hline 18 & Spatial Orientation & $\begin{array}{l}\text { The ability to know your location in relation to the } \\
\text { environment or to know where other objects are in relation }\end{array}$ \\
\hline
\end{tabular}


19 Visualization

20 Selective Attention

21 Time Sharing to you.

The ability to imagine how something will look after it is moved around or when its parts are moved or rearranged. The ability to concentrate on a task over a period of time without being distracted.

The ability to shift back and forth between two or more activities or sources of information (such as speech, sounds, touch, or other sources).

\section{Psychomotor Abilities \\ 22 Arm-Hand Steadiness}

\section{Manual Dexterity}

\section{Finger Dexterity}

\section{Control Precision}

26 Multilimb Coordination

\section{Response Orientation}

\section{Rate Control}

\section{Reaction Time}

30 Wrist-Finger Speed

31 Speed of Limb Movement

\section{Static Strength}

33 Explosive Strength

34 Dynamic Strength

\section{Trunk Strength}

\section{Stamina}

\section{Extent Flexibility}

The ability to keep your hand and arm steady while moving your arm or while holding your arm and hand in one position.

The ability to quickly move your hand, your hand together with your arm, or your two hands to grasp, manipulate, or assemble objects.

The ability to make precisely coordinated movements of the fingers of one or both hands to grasp, manipulate, or assemble very small objects.

The ability to quickly and repeatedly adjust the controls of a machine or a vehicle to exact positions.

The ability to coordinate two or more limbs (for example, two arms, two legs, or one leg and one arm) while sitting, standing, or lying down. It does not involve performing the activities while the whole body is in motion.

The ability to choose quickly between two or more movements in response to two or more different signals (lights, sounds, pictures). It includes the speed with which the correct response is started with the hand, foot, or other body part.

The ability to time your movements or the movement of a piece of equipment in anticipation of changes in the speed and/or direction of a moving object or scene.

The ability to quickly respond (with the hand, finger, or foot) to a signal (sound, light, picture) when it appears.

The ability to make fast, simple, repeated movements of the fingers, hands, and wrists.

The ability to quickly move the arms and legs.
The ability to exert maximum muscle force to lift, push, pull, or carry objects.

The ability to use short bursts of muscle force to propel oneself (as in jumping or sprinting), or to throw an object. The ability to exert muscle force repeatedly or continuously over time. This involves muscular endurance and resistance to muscle fatigue.

The ability to use your abdominal and lower back muscles to support part of the body repeatedly or continuously over time without 'giving out' or fatiguing.

The ability to exert yourself physically over long periods of time without getting winded or out of breath.

The ability to bend, stretch, twist, or reach with your body, 
38 Dynamic Flexibility

39 Gross Body Coordination

40 Gross Body Equilibrium arms, and/or legs.

The ability to quickly and repeatedly bend, stretch, twist, or reach out with your body, arms, and/or legs.

The ability to coordinate the movement of your arms, legs, and torso together when the whole body is in motion.

The ability to keep or regain your body balance or stay upright when in an unstable position.

\begin{tabular}{|c|c|c|}
\hline \multicolumn{3}{|c|}{ Sensory Abilities } \\
\hline 41 & Near Vision & $\begin{array}{l}\text { The ability to see details at close range (within a few feet of } \\
\text { the observer). }\end{array}$ \\
\hline 42 & Far Vision & The ability to see details at a distance. \\
\hline 43 & Visual Color Discrimination & $\begin{array}{l}\text { The ability to match or detect differences between colors, } \\
\text { including shades of color and brightness. }\end{array}$ \\
\hline 44 & Night Vision & The ability to see under low light conditions. \\
\hline 45 & Peripheral Vision & $\begin{array}{l}\text { The ability to see objects or movement of objects to one's } \\
\text { side when the eyes are looking ahead. }\end{array}$ \\
\hline 46 & Depth Perception & $\begin{array}{l}\text { The ability to judge which of several objects is closer or } \\
\text { farther away from you, or to judge the distance between } \\
\text { you and an object. }\end{array}$ \\
\hline 47 & Glare Sensitivity & $\begin{array}{l}\text { The ability to see objects in the presence of glare or bright } \\
\text { lighting. }\end{array}$ \\
\hline 48 & Hearing Sensitivity & $\begin{array}{l}\text { The ability to detect or tell the differences between sounds } \\
\text { that vary in pitch and loudness. }\end{array}$ \\
\hline 49 & Auditory Attention & $\begin{array}{l}\text { The ability to focus on a single source of sound in the } \\
\text { presence of other distracting sounds. }\end{array}$ \\
\hline 50 & Sound Localization & $\begin{array}{l}\text { The ability to tell the direction from which a sound } \\
\text { originated. }\end{array}$ \\
\hline 51 & Speech Recognition & $\begin{array}{l}\text { The ability to identify and understand the speech of another } \\
\text { person. }\end{array}$ \\
\hline 52 & Speech Clarity & The ability to speak clearly so others can understand you. \\
\hline
\end{tabular}

Source: O*NET Resource Center 2017. 